\title{
Aligning environmental management with ecosystem resilience: a First Foods example from the Confederated Tribes of the Umatilla Indian Reservation, Oregon, USA
}

\author{
$\underline{\text { Eric J. Quaempts }}^{1}$, Krista L. Jones $^{2}, \underline{\text { Scott J. O'Daniel }}^{1}, \underline{\text { Timothy J. Beechie }}^{3}$ and Geoffrev C. Poole ${ }^{4,5}$
}

\begin{abstract}
The concept of "reciprocity" between humans and other biota arises from the creation belief of the Confederated Tribes of the Umatilla Indian Reservation (CTUIR). The concept acknowledges a moral and practical obligation for humans and biota to care for and sustain one another, and arises from human gratitude and reverence for the contributions and sacrifices made by other biota to sustain human kind. Reciprocity has become a powerful organizing principle for the CTUIR Department of Natural Resources, fostering continuity across the actions and policies of environmental management programs at the CTUIR. Moreover, reciprocity is the foundation of the CTUIR "First Foods" management approach. We describe the cultural significance of First Foods, the First Foods management approach, a resulting management vision for resilient and functional river ecosystems, and subsequent shifts in management goals and planning among tribal environmental staff during the first decade of managing for First Foods. In presenting this management approach, we highlight how reciprocity has helped align human values and management goals with ecosystem resilience, yielding management decisions that benefit individuals and communities, indigenous and nonindigenous, as well as human and nonhuman. We further describe the broader applicability of reciprocity-based approaches to natural resource management.
\end{abstract}

Key Words: Confederated Tribes of the Umatilla Indian Reservation; ecosystem resilience; First Foods; reciprocity; resilient rivers; tribal environmental management

\section{INTRODUCTION}

Human communities depend on ecosystems for many services, such as drinking water, food, and building materials. One consequence of this dependence is ecosystem simplification as human actions tend to reduce the spatial and temporal complexity of ecosystems in order to maximize resource productivity and streamline management and harvesting actions. This simplification, in turn, can diminish ecosystem resilience. Resilience has many facets, including the capacity of an ecosystem to return to a reference state after a temporary disturbance (Grimm and Wissel 1997) and the amount of change that an ecosystem can absorb before governing processes shift, moving an ecosystem to an alternative stable state (Holling 1973). As resilience is diminished, ecosystems often lose their long-term viability and capacity to produce ecosystem services (Folke et al. 2010).

Environmental management strategies increasingly are focused on managing and restoring ecosystem resilience across landscapes where returning to predisturbance conditions is not a viable option (Folke et al. 2004, Chapin et al. 2010). Motivations include the ethical responsibilities of present-day generations to future generations and the need to manage for ecosystems that can withstand climate change (Waples et al. 2009, Anderson and Ferree 2010, Beier and Brost 2010, Chapin et al. 2011, Beechie et al. 2013). Managing for ecosystem resilience instead of short-term resource extraction involves a fundamental shift from managing ecosystems that are simple and static to managing ecosystems that are complex and dynamic in space and time (sensu Peipoch et al. 2015) as well as adaptive learning and management (Gunderson 2000). Substantive questions remain as this management shift evolves. For instance, how can environmental management support resilient ecosystems, which in turn support the individual and societal needs of humans? What are the management approaches for balancing resilient ecosystems and resource use? How do environmental managers communicate management and restoration actions related to ecosystem resilience to their constituents? How do agencies shift to managing for ecosystem resilience and natural processes within an interagency context?

We offer the "First Foods" management approach of the Confederated Tribes of the Umatilla Indian Reservation (CTUIR) as a case study providing viable responses to such questions. The CTUIR Department of Natural Resources's (DNR) First Foods approach has the following distinguishing components, which are described in detail below: (1) the explicit acknowledgement of reciprocity between humans and the environment as reinforced by the CTUIR's creation belief and ritual serving order for culturally significant foods; (2) a departmental mission and structure organized by the First Foods approach; (3) the recognition and emphasis on the ecological ordering of First Foods; (4) the recognition of the spatial distribution of foods as modeled in the serving order, and (5) the identification of linkages between the serving order and the Walla Walla Treaty of 1855 , thereby informing and enriching intergovernmental relations and collaborative opportunities. We

\footnotetext{
${ }^{1}$ Department of Natural Resources of the Confederated Tribes of the Umatilla Indian Reservation, Mission, OR, ${ }^{2}$ USGS Oregon Water Science Center, Portland, OR, ${ }^{3}$ Fish Ecology Division, Northwest Fisheries Science Center, National Marine Fisheries Service, National Oceanic and Atmospheric Administration, Seattle, WA, ${ }^{4}$ Department of Land Resources and Environmental Sciences, Montana State University, Bozeman, MT, ${ }^{5}$ Institute on Ecosystems, Montana State University, Bozeman, MT
} 
Fig. 1. The diminished Umatilla Indian Reservation and where the three bands of the Confederated Tribes of the Umatilla Indian Reservation (the Cayuse, Umatilla, and Walla Walla people) historically traveled to hunt, fish, gather, socialize, and trade. Data and information used to create this map include the 1855 Treaty negotiation minutes, adjudicated use areas, oral histories information, and documentation from literature.

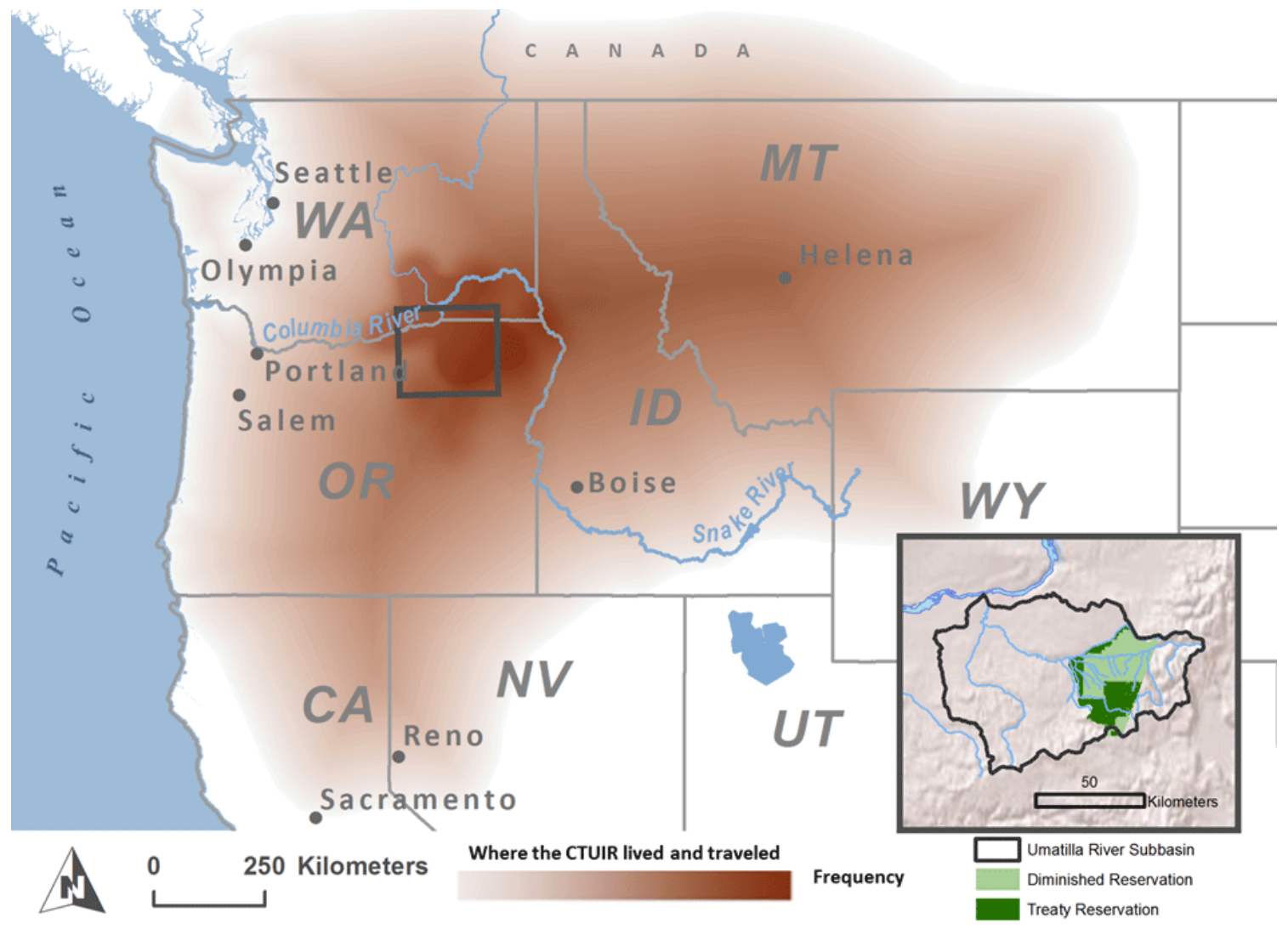

offer insights into how ecosystem resilience can be incorporated into environmental management strategies in ways that are meaningful to communities, helpful for interagency collaboration, and adaptable by other natural resource management entities. We describe the cultural basis of the First Foods, the CTUIR's use of resource visions to implement the First Foods management approach, and subsequent shifts in planning and goals among tribal environmental staff in their first decade of managing for First Foods. We also discuss how the First Foods approach may act as a lens for understanding natural resource stewardship in a way that resonates with people of diverse cultures and belief systems.

\section{BACKGROUND}

The Confederated Tribes of the Umatilla Indian Reservation The CTUIR encompasses three tribal bands of confederacy, the Umatilla, Walla Walla, and Cayuse. The diminished Umatilla Indian Reservation (UIR) covers 6900 ha in northeastern Oregon (Fig. 1). The total CTUIR population was about 3075 members in 2016 (E. Lubrin, personal communication, CTUIR Enrollment Office, November 2016). About 4340 people, including CTUIR members, other tribal members, and nontribal members, resided on the UIR as of 2015-2016 (Umatilla-Morrow Counties Community Health Partnership 2016).
The CTUIR negotiated for the UIR and its ceded lands of 6.4 million acres (nearly 2,590,000 ha) in the Walla Walla Treaty of 1855 with the United States. On these ceded lands, the CTUIR retains rights to access and harvest treaty-reserved resources on open and unclaimed federal lands. Beyond these ceded lands is an extensive aboriginal use area that has been documented through oral histories and published literature (Hunn et al. 2015). The CTUIR manages for tribal natural resources and access to them on the UIR, ceded lands, and aboriginal use area through its own governance and intergovernmental relationships with local, state, and federal governments. The CTUIR actively collaborates with other natural resource agencies on lands outside the UIR because of tribal historical patterns of landscape use (Fig. 1), reserved Treaty rights, and the fact that lands within the diminished reservation boundary cannot provide the CTUIR with all First Foods (Fig. 2).

\section{Cultural significance of First Foods}

Food is integral to CTUIR ceremonies and traditions, as it is in other cultures, such as the feast of Thanksgiving in U.S. culture and the symbolic consumption of bread and wine in Christian ceremonies (The Holy Bible, Luke 22:19). At ceremonial feasts, the CTUIR people honor the five First Foods by serving them formally and before any other foods (Fig. 3). Four emblematic 
Fig. 2. Potential distributions of some First Foods of the Confederated Tribes of the Umatilla Indian Reservation, including: (A) Water: the stream network of the Umatilla River from the NHD Plus Version 2 (Horizon Systems 2013), (B) Salmon: the potential range of Pacific salmon (Confederated Tribes of the Umatilla Indian Reservation v. U.S. 1959), (C) Roots: modeled plant distributions associated with roots that serve as First Foods (Schumacher 2014), and (D) Berries: modeled plant distributions associated with huckleberries (Schumacher 2016).

A

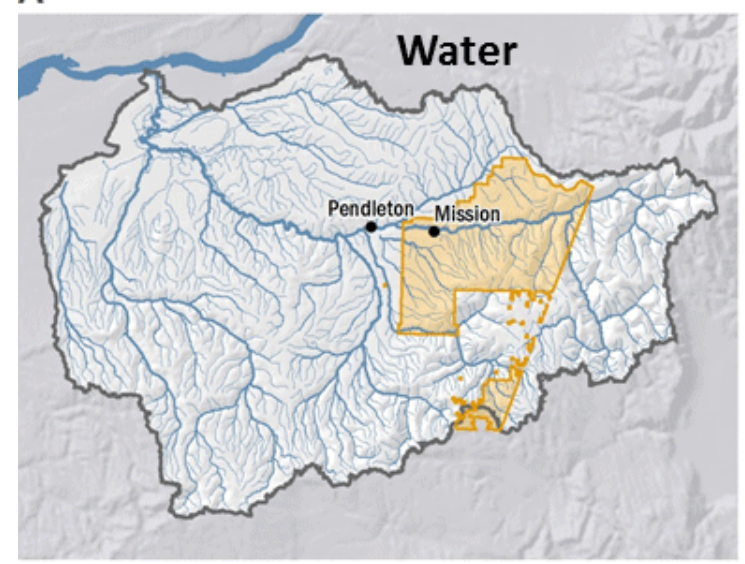

C

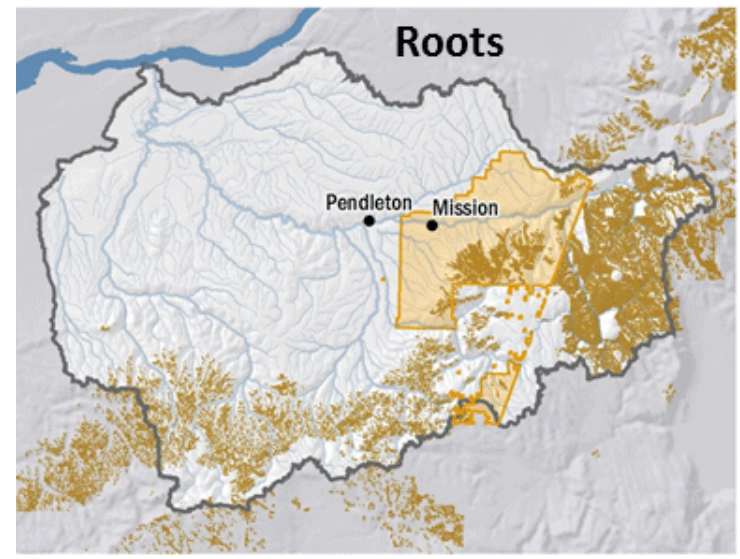
A

0

25 Kilometers 25
First Foods, fish, big game, roots, and berries, are served in the order in which these foods promised to care for the Indian people according to the CTUIR creation belief (Relander 1986, Karson 2006, Confederated Umatilla Journal 2008). In the creation belief, "the Creator asked [of the creatures of the Earth], "Who will take care of the people?" Salmon said "I will" and the other fish lined up behind him, then the deer made a promise, and so on" (Confederated Umatilla Journal 2008). Water, the fifth First Food, is served before and after the four emblematic First Foods, in recognition of the fact that water is singularly essential, nourishing all other First Foods, people, and the landscape. Without water, none of the other First Foods can exist. The community celebrates First Foods when harvesting foods for feasts, everyday use after feasts, and honoring a tribal member's first harvest of a First Food. They practice the serving order at funerals, memorials, naming of individuals, and weekly services
B

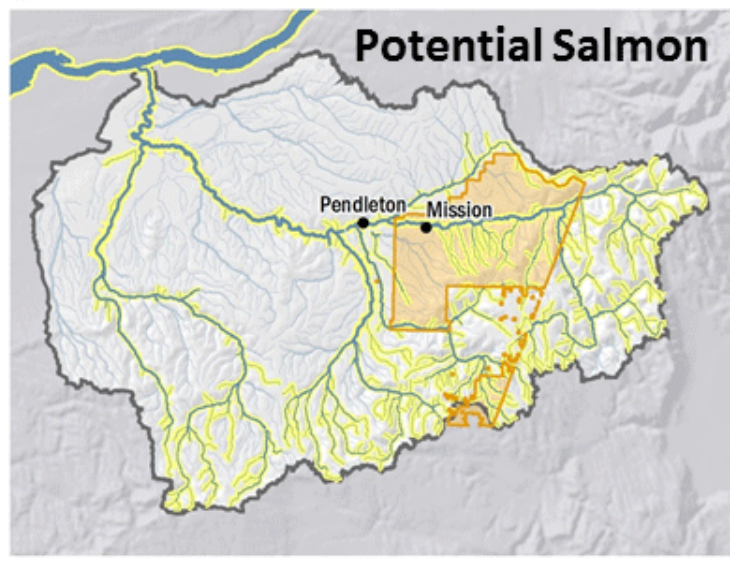

D

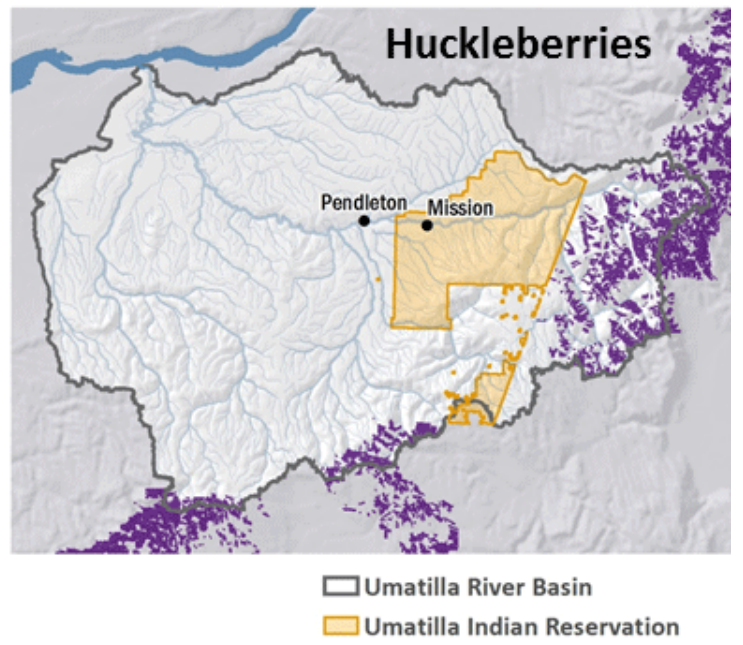

of the Washat, the religion of the Columbia Plateau tribes (Relander 1986). For First Foods feasts and other ceremonial meals, men serve the water and harvest and serve the fish and big game, while women harvest and serve the roots and berries (Fig. 3 ). These harvest gender roles may or may not be strictly followed during other times of the year, such as when harvesting for familial and personal use. The CTUIR community does not include any nontraditional foods in the First Foods serving order and ritual despite the introduction and abundance of new foods. For example, Smallmouth Bass (Micropterus dolomieu), a widespread introduced fish in the Pacific Northwest (Carey et al. 2011), is not used as a substitute for native fishes, nor wheat for roots. Instead, nonindigenous foods are served at ceremonies and feasts only after the ritual serving of First Foods, and without ceremony or significance. First Foods in these acts of ceremony and religion define and reinforce the identities of individuals, families, and the 
Fig. 3. An example of the serving order of the Confederated Tribes of the Umatilla Indian Reservation. Foods are served in the order in which foods promised to care for the tribal people. This serving order includes some examples of culturally significant First Foods, but is not a comprehensive table setting. For First Foods feasts and other ceremonial meals, men harvest the fish and big game and serve the water, fish, and big game while women harvest and serve the roots and berries. These harvest gender roles are not strictly followed during other times of the year, such as when harvesting for familial and personal use. Images courtesy of the Integration and Application Network, University of Maryland Center for Environmental Science (http://ian.umces.edu/ symbols/).

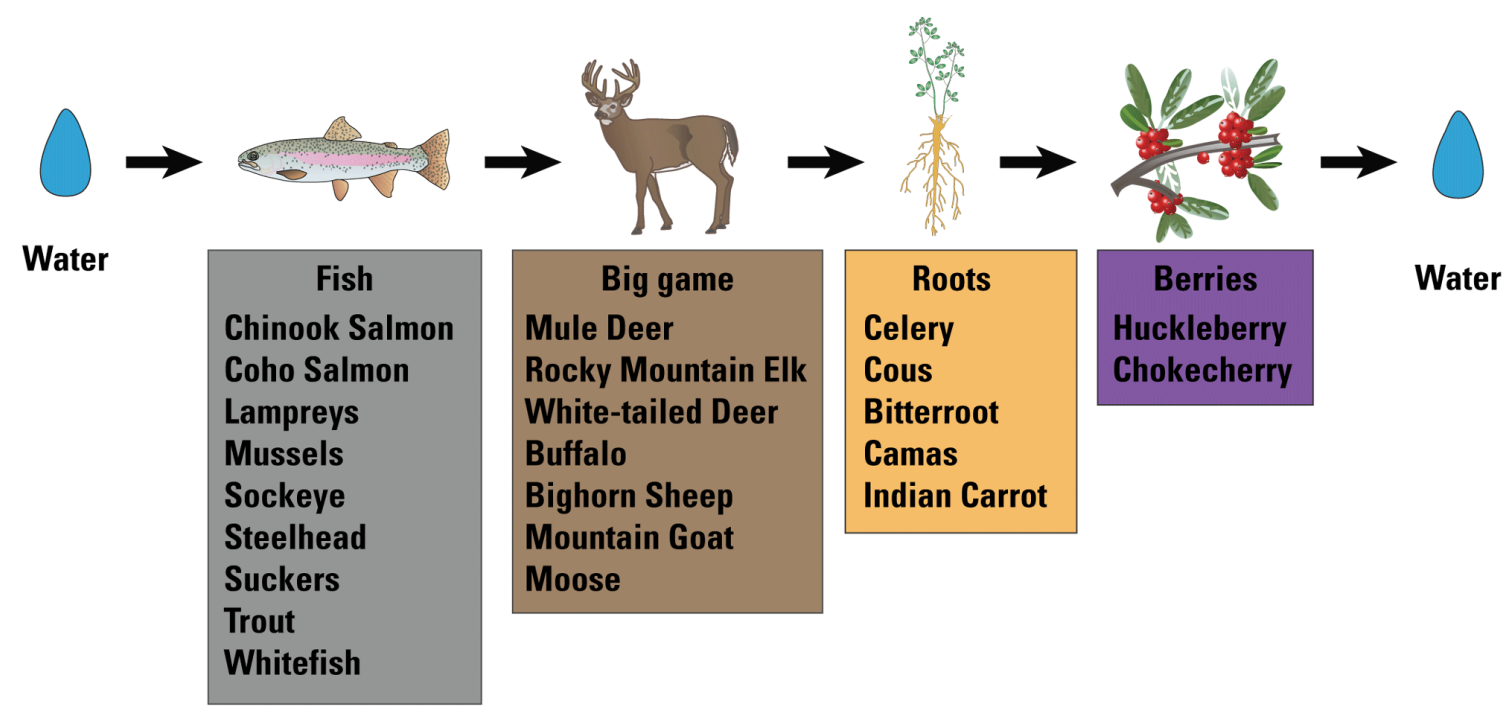

Formal harvesting and serving roles for First Foods feasts and ceremonial meals

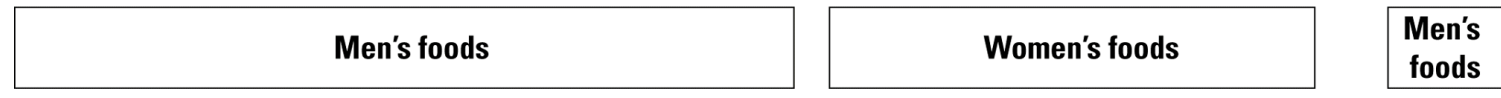

tribal community (sensu Holtzman 2006), and signify the enduring linkages between the CTUIR people and their food, values, and environment.

The CTUIR's creation belief also reinforces "reciprocity" between First Foods and the CTUIR people, meaning First Foods promised to care for the people and the people are responsible for the care and protection of First Foods. Since time immemorial, the CTUIR has benefited from First Foods used for subsistence, ceremony, and medicine. Tribal members benefit from the nutrition and exercise associated with traditional practices and access to traditional resources (Kuhnlein and Receveur 1996, Cochran and Geller 2002, Hess et al. 2008). Data on the proportion of First Foods in the CTUIR's diet are unavailable; however, steady participation at feasts, regular use of First Foods for subsistence by tribal members, and increasing awareness of the health benefits of a traditional diet reflect the dietary importance of First Foods to the CTUIR. In turn, the CTUIR people take care of First Foods through actions that support resilient ecosystems and First Foods. For instance, rootharvesting practices include leaving most roots to complete their life cycle at harvesting sites, replanting the flowering heads of harvested roots for continued production, or postponing harvest until seeds have dropped. Similarly, individuals leave some berries on huckleberry bushes for forage by bears and other animals and to encourage continued berry production. Such explicit, intentional, and enduring actions emphasize and prioritize ecosystem resiliency over short-term maximization of resource extraction. Moreover, these expressions of reciprocity reflect a recent shift in CTUIR individual and community actions from solely supporting concepts of western culture, such as "sustainability," toward reembracing the traditional concepts of supporting and sustaining First Foods and their cultural, religious, and subsistence significance in honor of the promises made by the First Foods to care for the CTUIR people.

\section{Diminishment of First Foods}

From time immemorial to Euro-American settlement and the Walla Walla Treaty of 1855, dynamic natural processes and tribal practices maintained plentiful First Foods (Fig. 4). Water from melting snow pack fed the rivers, connecting them seasonally with their floodplains. Fires ignited by thunderstorms reset terrestrial vegetation communities, and helped supply rivers with new spawning gravels for salmon and lamprey. Big game First Foods, such as mule deer (Odocoileus hemionus), elk (Cervus canadensis), and bighorn sheep (Ovis canadensis; Fig. 3) migrated across the landscape unencumbered by fences and other artificial barriers. Meanwhile, the CTUIR, like other tribes in the Pacific Northwest, used fire to manage huckleberry fruit production (Minore 1972, Fisher 1997) and create foraging areas for big game. They harvested foods across the dynamic landscape in synchrony with plant phenology and food availability. The arrival of horses on tribal lands in 1770 increased tribal access to all First Foods because they helped the CTUIR tribal members expand their range for hunting and harvesting (Figs. 1, 4). 
Fig. 4. Timeline of representative events benefiting or diminishing First Foods and tribal access to them, time immemorial to 1913.

\section{CTUIR First Foods Plentiful and then Diminishing: Time Immemorial to 1913}

\section{Events that Benefited CTUIR Members, First Foods, and Tribal Access}

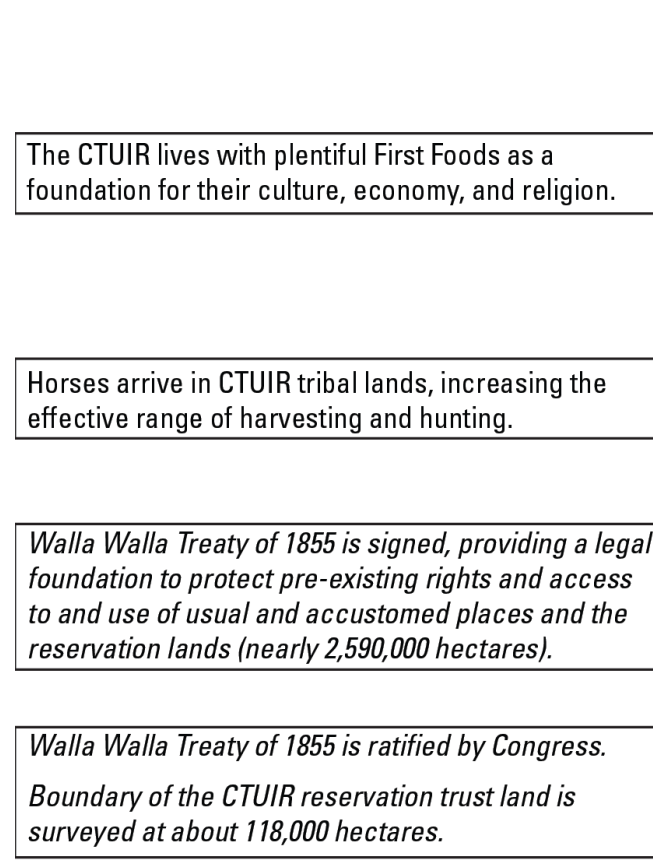

The Supreme Court case U.S. v. Winans holds that treaty Indians have the right to cross non-Indian lands to fish at "usual and accustomed" places, and that the treaties are to be interpreted the way Indians had understood them.

Supreme Court decision in Winters v. United States holds that tribes received a federal reserved water right to satisfy the principal purposes for which the reservation was created with a priority date of the Treaty. Later, a 9th Circuit case held instream flow right had a time immemorial priority date.

\section{Events that Impaired CTUIR Members, First Foods, and Tribal Access}

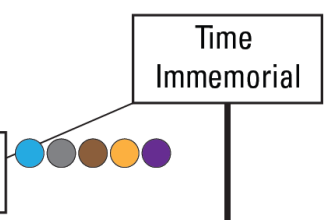

\begin{tabular}{|ll|}
\hline Explanation & \\
First Foods & Event type \\
Water & Physical action \\
Fish & Legal or policy action \\
Big game & Observation \\
Roots & Scientific data collection \\
Berries & \\
\hline
\end{tabular}

Railroad line is built across the Umatilla Indian Reservation (UIR).

The Slater Allotment Act reduces CTUIR reservation trust lands from about 99,400 hectares to about 63,900 hectares, and places CTUIR under land allotments.

The result of the Dawes Act was the reduction of CTUIR ownership by more than 30\%. The Dawes Act opened the Reservation to Euro-American settlement.

Cession of thousands of hectares of CTUIR reservation trust lands is ordered by the U.S. Secretary of Interior.

Reclamation Act approved by Congress to provide water storage and delivery facilities to western U.S.

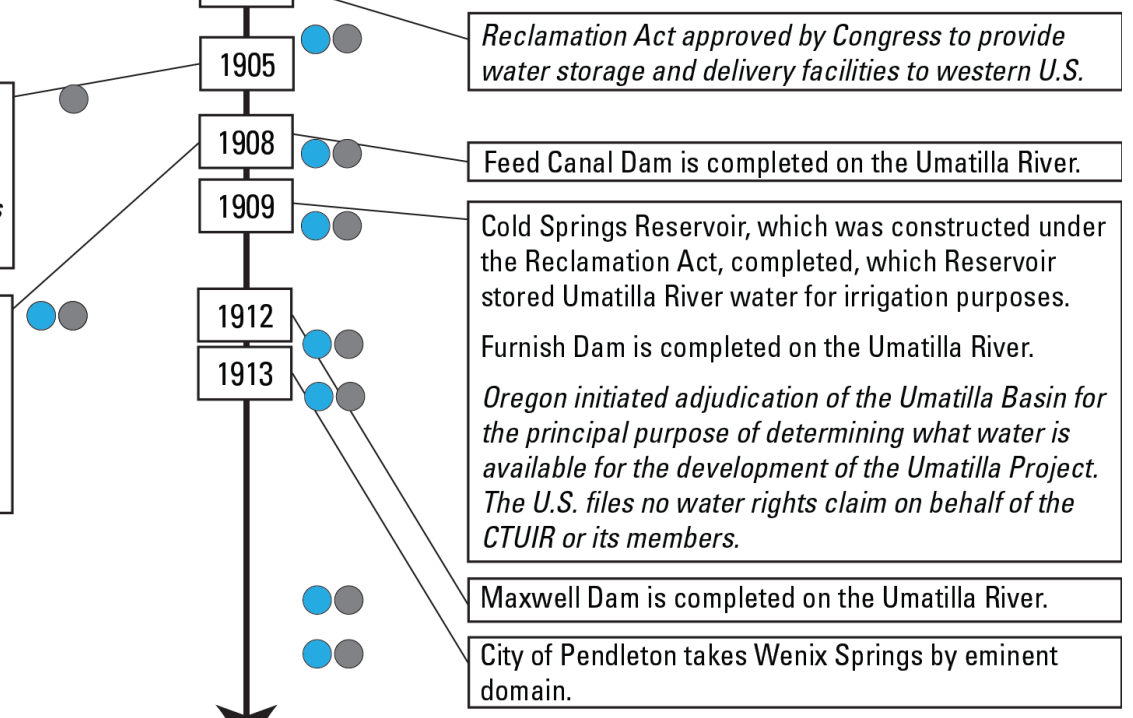


Accessibility and abundance of First Foods began to decline for the CTUIR with Euro-American settlement and later substantial reductions in the area of the UIR. The UIR was reduced from over 99,000 ha to about 64,000 ha over the course of four reductions from 1885 to 1888 (Fig. 4). Resource use by the expanding non-native human population increasingly was dominated by extractive and intensive management approaches, rather than by a culture of reciprocity and support of resilient ecosystems. For example, Euro-American management has included the extraction of mineral and water resources and intensive management of agricultural lands for single crops; such management focuses on the production of a limited number of resources at the expense of numerous others and on controlling natural processes that create habitat and biological diversity across the landscape. As a result, the physical, biological, and ecological processes that support First Foods have been impaired by many changes, such as dams, floodplain simplification, fire suppression, water extraction, pollution, grazing, deforestation, commercial and irrigated agriculture, crop introductions, and placer and gravel mining. These changes along with EuroAmerican suppression of CTUIR natural resource management, cultural expressions, and religious practices contributed to the simplification of native ecosystems and the eventual decline of many culturally important resources (Figs. 4-6).

In this modern landscape, many First Foods, such as salmon, lampreys, and mussels, have declined precipitously (Gresh et al. 2000). For example, over 10-16 million salmon and steelhead (Oncorhynchus spp.) returned to the Columbia River historically; these runs declined to 5-8 million (a 50\% loss) from the 1800 s to the 1930s because of overharvest and habitat degradation, and then declined further to 1-2 million (a 90\% loss) since the construction of the mainstem Columbia River dams (Montgomery 2003; Figs. 5-7). As early as 1926, the Oregon Department of Fish and Wildlife found no Chinook (Oncorhynchus tshawytscha) or Coho (O. kisutch) salmon in the Umatilla River (Boyce 1986; Fig. 5). Multiple salmonid Evolutionary Species Units (ESUs) were listed as "Endangered" or "Threatened" under the Endangered Species Act (ESA) from 1991 to 1999 and Pacific Lamprey (Entosphenus tridentatus) were petitioned for listing in 2003 (Figs. 7, 8). Today, the salmonids remain listed under the ESA (Fig. 9). In addition, Pacific lamprey numbers remain low in the Umatilla basin, requiring the CTUIR to travel more than $360 \mathrm{~km}$ to collect Pacific Lamprey at Willamette Falls near Portland, Oregon. Other First Foods, such as huckleberries (Vaccinium spp.), are commercially harvested by nontribal individuals from federal lands in manners that threaten their availability to tribal members (Minore et al. 1979).

\section{CTUIR NATURAL RESOURCE MANAGEMENT}

Prior to the creation of the CTUIR's Department of Natural Resources, the abundance and availability of First Foods were conserved by Supreme Court rulings, the Clean Water Act, the ESA, and the collective scientific, habitat restoration, and policy actions of the CTUIR (Figs. 5-8). For example, the Supreme Court case U.S. v. Winans (1905) established that tribes retained sovereignty and reserved rights to continue their ways of life through the treaty negotiations and that the U.S. has federal trust responsibility to the tribes (Blumm and Swift 1998, Pevar 2012). This means that the CTUIR retained their rights to the access and use of usual and accustomed places and reservation lands as identified and negotiated in the Walla Walla Treaty of 1855 (Figs. $1,4)$. The CTUIR also shares governance of natural resources with federal and state agencies, resulting from the treaty making process outlined in Article VI of the U.S. Constitution. For example, several federal departments, such as the Interior, Agriculture, Commerce, and Defense, are responsible for consulting with tribes on the management of federal actions that might affect tribal natural resources associated with the treaties between tribes and the U.S. Federal Government (Galanda 2011), and developing consultation policies focused on tribes (Executive Order No. 13175). The resulting government-to-government relationship enables tribes and the federal government to have discussions on issues of concern, including the management of resources important to tribal culture.

Within the CTUIR, governance for natural resources starts with the Board of Trustees (BOT). The BOT is a group of nine people elected by the General Council to protect the CTUIR rights as reserved in the Walla Walla Treaty of 1855, set policy, make final decisions on tribal affairs, and determine priority projects and issues on behalf of the CTUIR and residents of the UIR. The BOT formed the DNR in 1982 to manage resources on the reservation and, in collaboration with state and federal agencies, on ceded lands and in aboriginal use area (Fig. 1). The original mission of the DNR was to "... protect, enhance and restore the natural and cultural heritage of the CTUIR by ensuring the longterm health, availability, wise-use, and production of the tribe's natural and cultural resources in a manner consistent with Tribal values and scientifically sound resource management" (CTUIR 2005:2). In 2005, the DNR consisted of six programs: Administration, Cultural Resources Protection, Water Resources, Fisheries, Wildlife, and Environmental Planning and Rights Protection Programs. The DNR has grown substantially in terms of staff, number of projects, budgets, and number of cooperating agencies from 1995 to 2015 (Table 1).

Table 1. Staffing, number of projects, and number of cooperating agencies for the Department of Natural Resources for the Confederated Tribes of the Umatilla Indian Reservation, 1995 to 2015.

\begin{tabular}{lccc}
\hline \hline Years & $\begin{array}{c}\text { Number of } \\
\text { employees }\end{array}$ & $\begin{array}{c}\text { Number of } \\
\text { projects }\end{array}$ & $\begin{array}{c}\text { Number of } \\
\text { cooperating } \\
\text { agencies }\end{array}$ \\
\hline $1995-1999$ & 80 & 78 & 13 \\
$2000-2004$ & 85 & 143 & 34 \\
$2005-2010$ & 109 & 174 & 42 \\
$2011-2015$ & 127 & 186 & 43 \\
\hline
\end{tabular}

\section{CTUIR DNR efforts, 1982 to 2005}

The DNR faced many challenges in its first 23 years of managing for natural resources. The main challenge, then and today, is securing CTUIR water rights for instream flows and consumptive uses to meet the needs of the UIR community and fulfill the purpose of the UIR as the CTUIR's homeland. As of 2018, these water rights have not been secured, and the CTUIR is actively working with a federal negotiation team to permanently protect water, for both instream and consumptive uses. The process of securing rights has been ongoing since the 1980s and the passage 
Fig. 5. Timeline of representative events benefiting or diminishing First Foods and tribal access to them, 1914 to 1969.

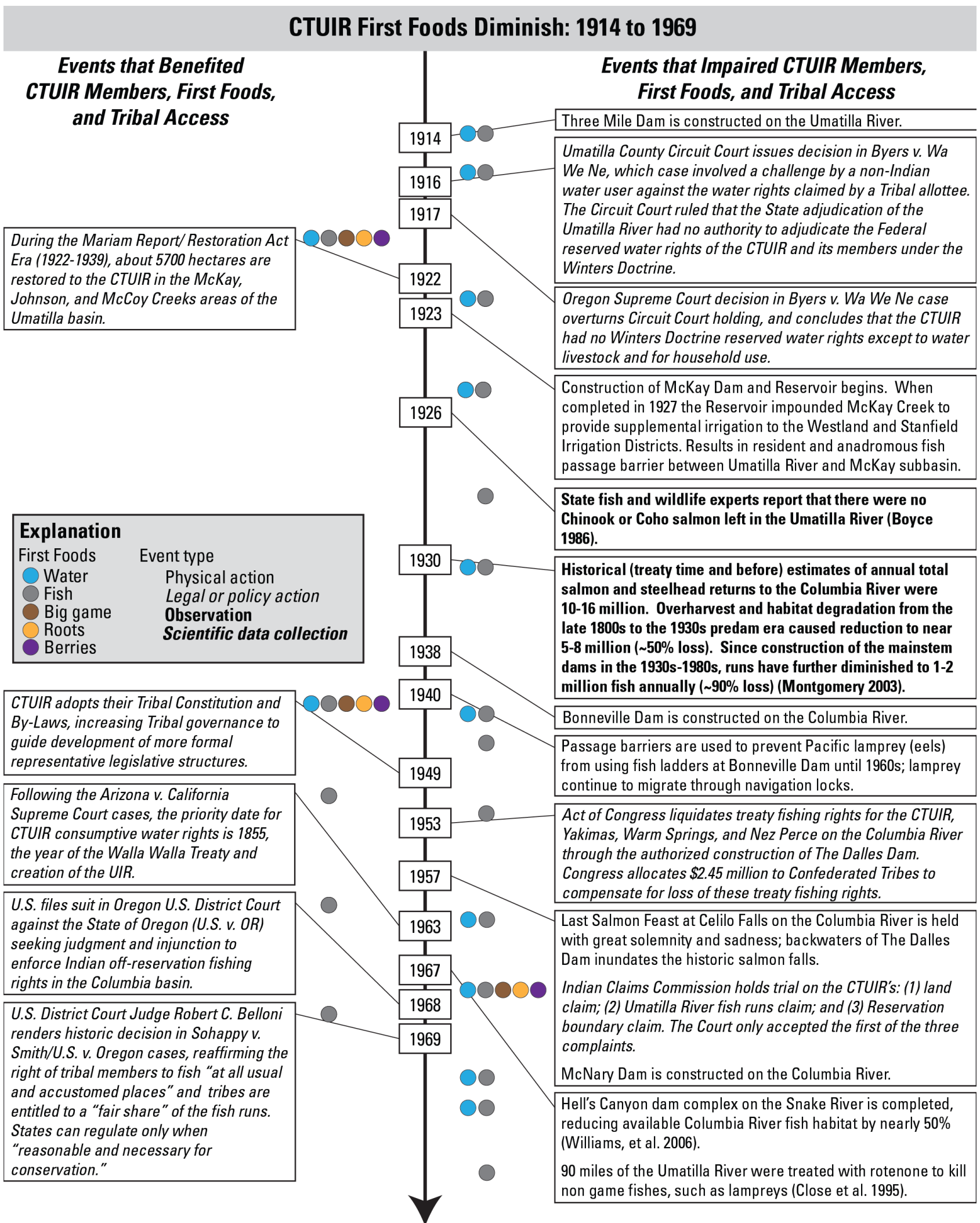


Fig. 6. Timeline of representative events benefiting or diminishing First Foods and tribal access to them, 1970 to 1982.

CTUIR First Foods Improving: 1970 to 1982

Events that Benefited CTUIR Members, First Foods, and Tribal Access

\begin{tabular}{|l|}
\hline The Clean Water Act is passed. \\
\hline The Endangered Species Act is passed. \\
\hline CTUIR files suit to enjoin proposed dam on Catherine Creek as an \\
irreparable loss of fishing, hunting, berry, and root gathering as \\
guaranteed under Treaty. The dam is not constructed. \\
In U.S. v. Washington, Judge Boldt mandates that a tribal "fair share" of \\
fisheries is $50 \%$ of the harvestable fish destined to pass "usual and \\
accustomed places," and reaffirms tribal management powers. \\
In Settler v. Lameer, federal court rules that tribes reserved the authority \\
to regulate tribal fishing on and off reservations in treaties. \\
Judge Belloni applies Judge Boldt's 50-50 allocation to Columbia River to \\
uphold rights of CTUIR and other tribes to fish in usual and accustomed \\
places for \\
and other fishes; Oregon and Washington are ordered to work out \\
comprehensive plan for preservation and conservation of fish resources.
\end{tabular}

The Columbia River Inter-Tribal Fisheries Enforcement (CRITFIC) department is established.

First Fish and Wildlife Code for CTUIR is established to govern activities (such as setting salmon harvest seasons) for Tribal members.

Establishment of the First Fish and Wildlife Committee to review policies and set priorities for CTUIR government.

Opening of CTUIR Longhouse provides a location central to the practice of community events (such as feasts, namings, and memorials).

Passing of the American Indian Religious Freedom Act allows access to sacred sites, freedom to worship through ceremonial and traditional rights, and the use and possession of objects considered sacred.

First wells installed to monitor groundwater on the CTUIR reservation.

BIA, Umatilla Agency establishes Wildlife Program.

The Northwest Power Act is passed.

CTUIR initiates Umatilla Salmon Recovery Project.

CTUIR's first reintroduction of spring Chinook salmon to Umatilla River. Interim Water Code is adopted.

CTUIR DNR forms through Board of Trustees resolution.

CTUIR DNR Water and Fisheries programs hire first staff.

First Fish and Wildlife Program under the NW Power and Planning Council calls for the Bonneville Power Administration to fund fish and wildlife mitigation projects.

First water permit is issued under Interim Water Code.

CTUIR adopts stream zone alteration regulations.

CTUIR releases spring and fall Chinook and Coho smolts in the Umatilla Basin to initiate reintroduction.

\section{Events that Impaired CTUIR Members, First Foods, and Tribal Access}

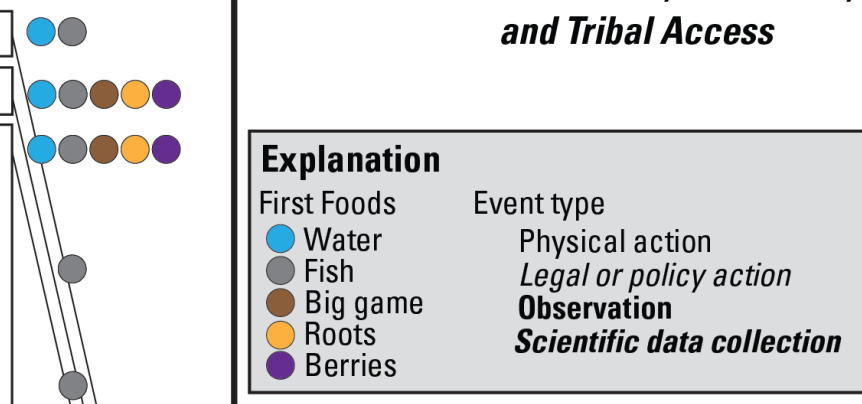

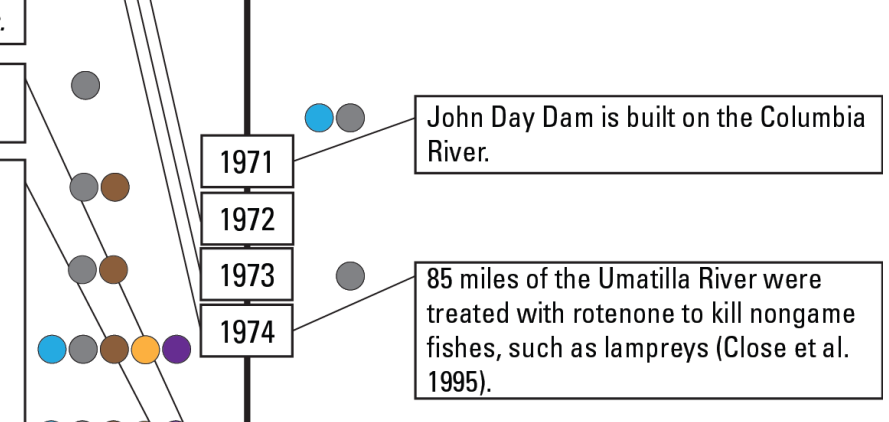


Fig. 7. Timeline of representative events benefiting or diminishing First Foods and tribal access to them, 1983 to 1999.

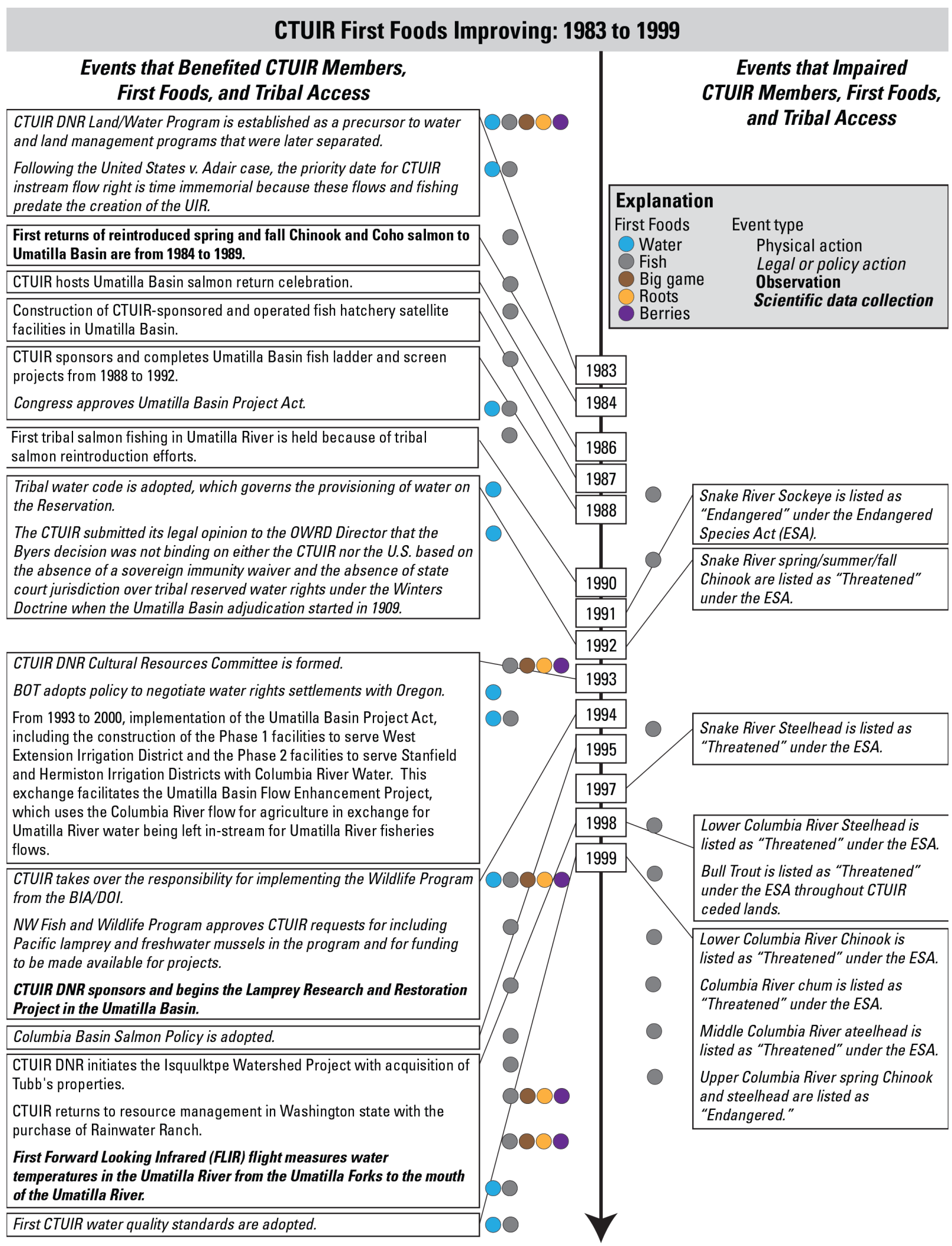


Fig. 8. Timeline of representative events benefiting or diminishing First Foods and tribal access to them, 2000 to 2009.

\section{CTUIR First Foods Improving: 2000 to 2009}

\section{Events that Benefited CTUIR Members, First Foods, and Tribal Access}

CTUIR DNR releases first translocated lamprey adults in the Umatilla Basin to initiate reintroduction.

NOAA and USFWS require 0.08 cubic-meters-per-second (cms) in the Walla Walla River at Milton-Freewater for threatened summer steelhead and endangered bull trout. Flow requirements were ramped up to 0.51, 0.71 , and $0.76 \mathrm{cms}$ in 2001-2003, respectively.

Solicitor of the Interior Department issues opinion that the 1917 Oregon Supreme Court decision in the Byers case is not binding on either the United States or the CTUIR because the Oregon courts did not have jurisdiction over CTUIR Federal reserved water rights when the decision was issued, nor had there been a waiver of the sovereign immunity of the United States or the CTUIR permitting Tribal water rights to be adjudicated in State Court.

CTUIR "Treatment-as-State" is determined by EPA and EPA approval of Tribal water quality standards.

CTUIR well construction standards are approved by Tribal Water Commission.

CTUIR DNR purchases Gladow properties on Meacham Creek.

CTUIR DNR releases first translocated freshwater mussels in Umatilla Basin to initiate reintroduction.

CTUIR's Umatilla Basin Water Rights Claims Report is prepared for CTUIR by Stetson Engineers Inc.

CTUIR Rocky Mountain goat and bighorn sheep hunting is restored.

CTUIR DNR adopts First Foods Mission.

Secretary of Interior appoints federal assessment team to assess CTUIR comprehensive water rights claims for Umatilla River in-stream flows and UIR consumptive use needs, and directs Bureau of Reclamation to do a water supply study to evaluate projects that could satisfy CTUIR water rights claims.

CTUIR assumes responsibility for Range/Agriculture Management Program from $B I A$.

CTUIR DNR reestablishes access to Teleocaset for root digging.

CTUIR BOT Chairman Antone Minthorn signs the 2008 Columbia Basin Fish Accords with BPA. This provides $\$ 168$ million for CTUIR fish and wildlife mitigation projects.

CTUIR DNR releases the Umatilla River Vision.

CTUIR assumes responsibility for Forest Management Program from BIA

CTUIR Cultural Resources Protection Program prepares "CTUIR

Traditional Relationship to Buffalo and Buffalo Hunting" report for Fish and Wildlife Commission's use in successfully negotiating treaty hunting rights for bison.

Watershed Ecology degree is codeveloped by CTUIR DNR and Walla Walla Community College (WWCC), approved by State of Washington, and offered by WWCC.

CTUIR begins installation of lamprey passage structures at Umatilla River irrigation diversion dams - first such action in Columbia Basin.
Events that Impaired CTUIR Members, First Foods, and Tribal Access

\begin{tabular}{|ll|}
\hline Explanation & \\
First Foods & Event type \\
Water & Physical action \\
Fish & Legal or policy action \\
Big game & Observation \\
Roots & Scientific data collection \\
Berries & \\
\hline
\end{tabular}


Fig. 9. Timeline of representative events benefiting or diminishing First Foods and tribal access to them, 2010 to 2017.

\section{CTUIR First Foods Improving: 2010 to 2017}

\section{Events that Benefited CTUIR Members, First Foods, and Tribal Access}

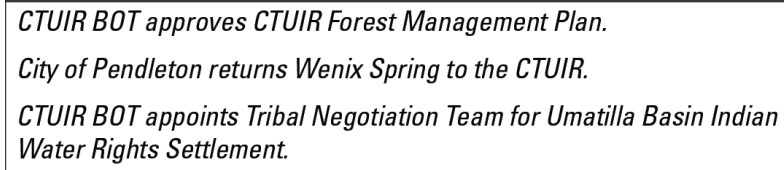

First documented return of the gray wolf to the UIR.

CTUIR has the first "Return to Bison" hunts in the greater Yellowstone ecosystem.

CTUIR DNR holds Traditional Foods Summit at the Society for Applied Anthropology Annual Meeting, Seattle, Washington.

In response to CTUIR-led efforts, the Oregon Environmental Quality Commission adopts fish consumption rate of $175 \mathrm{grams} /$ day to be more protective of Oregon's fish consumers.

CTUIR First Foods Policy Program is developed and replaces the CTUIR "Environmental Planning/Rights Protection" Program.

CTUIR BOT adopts Umatilla Basin water rights settlement proposal and initiates formal negotiations with Westland Irrigation District on a Columbia River trade project.

CTUIR opens seven ceded area tributaries for spring Chinook salmon subsistence fishing for tribal members. This represents the first time there has been that level of tribal fishing opportunity in about 40 years.

CTUIR DNR CRPP hosts 65th annual Northwest Anthropological Conference (NWAC) at Wildhorse Resort and Casino, marking the first time a tribe hosts the event and the first time the event is hosted on an Indian reservation.

The WWCC Water and Environmental Center Aquatic Lab opens for lamprey and mussel research and propagation for population restoration and tribal harvest.

Federal Assessment Team report to Interior Secretary concludes that the CTUIR has valid, unadjudicated water rights claims, there is an interest in the Basin to settle CTUIR claims, and there is a legal means to do so.

BOR issues it Umatilla Basin Water Supply Study that evaluated water supply projects that could satisfy CTUIR water rights claims.

Department of Interior appoints former Federal Indian Water Rights Assessment Team as Negotiating Team for Umatilla Basin Indian Water Rights Settlement.

CTUIR DNR Range/Agriculture and Forestry Program responds to a rapidly growing feral horse population by removing 213 feral horses from the CTUIR reservation.

Second FLIR flight measures water temperatures from the Umatilla Forks to the mouth of the Umatilla River.

CTUIR DNR Water Resources Program completes Upper Umatilla Basin water budget and conceptual groundwater model.

CTUIR completes eight years of fish passage, diversion ladder, and screening projects in the Walla Walla basin.

CTUIR Tribal Negotiation Team develops a Columbia River Trade Project proposal with Hermiston and Stanfield Irrigation Districts and several ditch companies.

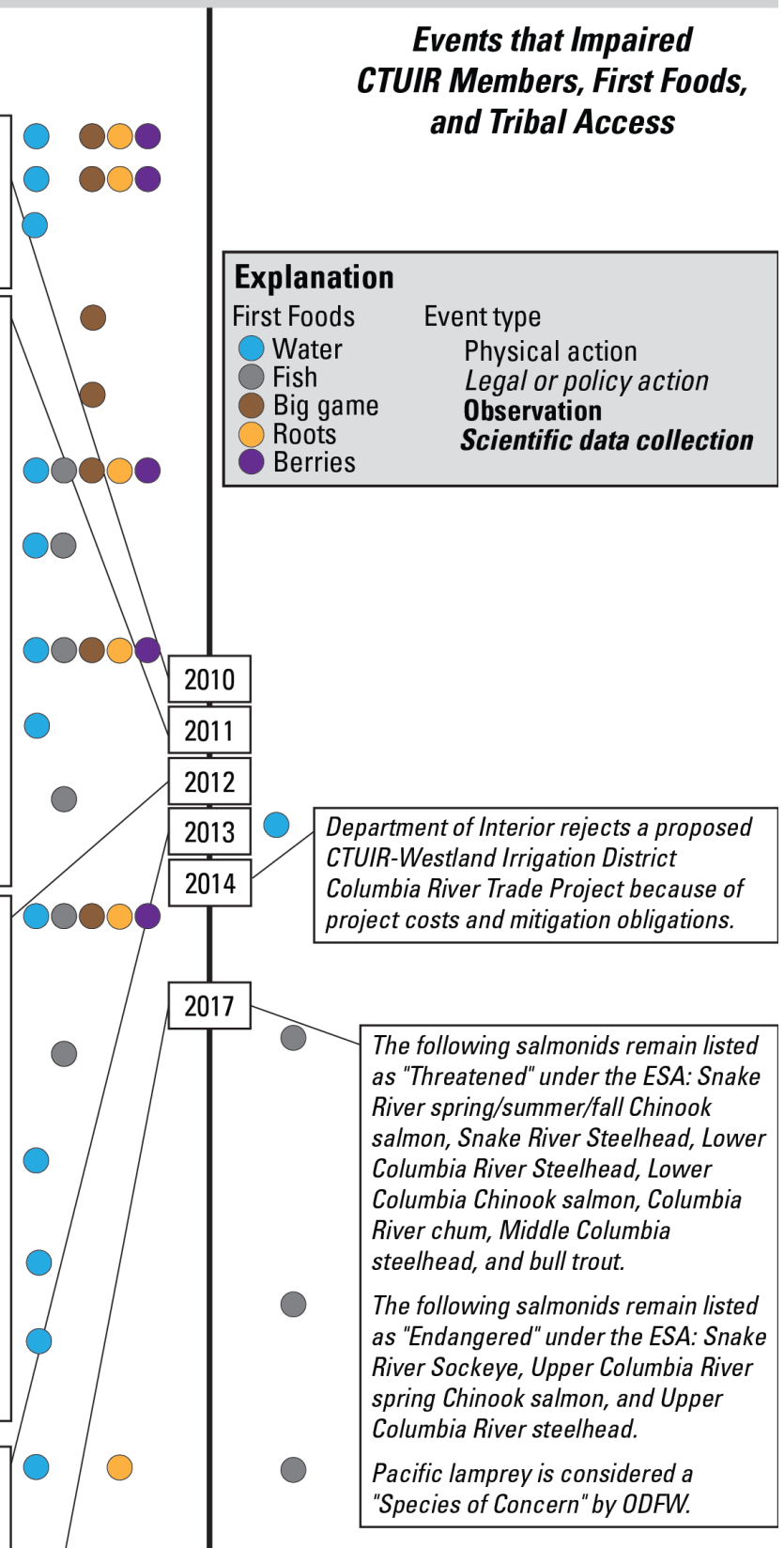


of the federal Umatilla Basin Project Act (U.S.C. Public Law 100-557) in 1988 (henceforth, UPB Act; Figs. 7-9).

A second challenge faced by the CTUIR DNR from 1982 to 2005 was the limited CTUIR governance capacity. This limited capacity restricted the scope of activities that the CTUIR was able to undertake and prevented them from pursuing multiple complex efforts simultaneously. This capacity has increased over time (Table 1; Figs. 7-8)

A third challenge faced by the CTUIR DNR from 1982 to 2005 was re-establishing extirpated salmon and lamprey in the mainstem Umatilla River through artificial propagation and fish supplementation programs (Figs. 7-8). The UPB Act helped provide some incremental progress toward improving base flows and fisheries in the Umatilla River because it allowed Umatilla Basin agricultural irrigators to use water instead from the Columbia River, leaving water in the Umatilla River during summer to support the artificial salmonid supplementation programs from 1993 to 1999 (Phillips et al. 2000, Shelley 2002). The UPB Act implementation required that the CTUIR DNR collaborate with the Oregon Department of Fish and Wildlife (ODFW), Bonneville Power Administration (BPA), the U.S. Bureau of Reclamation (BOR), Oregon Water Resources Department (OWRD), and the Hermiston, Stanfield, West Extension, and Westland Irrigation Districts. DNR staff operated fish supplementation facilities, and released spring and fall Chinook and Coho salmon (in 1982), Pacific lamprey (in 2000), and mussels (Bivalvia: Unionoida; in 2005) to initiate reintroduction in the Umatilla basin. Staff observed the first returns of reintroduced spring and fall Chinook and Coho salmon from 1984 to 1989, resulting in the CTUIR's Umatilla basin salmon return celebration in 1984 and the re-establishment of tribal salmon fishing in the Umatilla River in 1990 (Figs. 7-8). Positive outcomes of the UPB Act included the subsequent fishery and improved summer flows in the Umatilla River. The UPB Act also spurred the CTUIR to establish goals for salmon restoration, and enabled the CTUIR to take a coequal role in government-togovernment dialogues concerning natural resource issues. Irrigators, state water managers, local governments, and other cooperators recognized that the restoration of salmon to the Umatilla River would have been unlikely without the involvement, initiative, and persistence of the CTUIR DNR (Shelley 2002). Today, much work remains to continue to build on these successes in the lower Umatilla River basin where water quality, fish productivity, and habitat continue to persist at greatly suppressed levels of ecological function (Miller et al. 2007).

CTUIR DNR's First Foods management approach and mission, 2006-ongoing

Addressing the complex and inter-related challenges faced by the CTUIR DNR from 1982 to 2005 and responding to the CTUIR community's calls for management of all First Foods required that the CTUIR DNR adopt a more holistic and coherent approach, make the argument for increased organizational capacity, and prioritize management actions to meet community needs. Thus, in 2006, the "First Foods Management Approach and Mission" were introduced to DNR staff as a means of organizing DNR work goals and efforts in response to community cultural values and practices. Staff then reviewed the draft mission quarterly and multiple times with commissions, committees, and the BOT. Later that year, DNR proposed that the mission serve as the guiding element of the DNR's annual work plan. The BOT approved the adoption of the mission and its implementation, starting 1 January 2007, as follows:

To protect, restore, and enhance the First Foods - water, salmon, deer, cous, and huckleberry - for the perpetual cultural, economic, and sovereign benefit of the CTUIR. We will accomplish this utilizing traditional ecological and cultural knowledge and science to inform: 1) population and habitat management goals and actions; and 2) natural resource policies and regulatory mechanisms. (CTUIR 2006:2)

This mission statement is a community-driven management response to the incapacity of the present-day local landscape and UIR to support the full table setting for ceremony and subsistence uses (Fig. 2),

In 2007, the DNR was reorganized into five programs that relate directly to the major divisions in the First Foods serving order (Fig.3): Water - Water Resources Program, Fish - Fisheries Program, Big Game - Wildlife Program, Roots - Range Program, and Berries - Forestry Program. Three other DNR programs (Cultural Resources Protection Program, Outreach and Educations Specialist, and First Foods Policy Program) supports all foods in their work. The DNR now has about 127 staff, reflecting the department's growing capacity (Table 1). The inclusion of the First Foods in the DNR's mission statement also provides guidance to tribal programs that assist in the planning and implementation of DNR efforts, such as the Geographic Information Systems program and Office of Legal Counsel. For the CTUIR DNR and other programs, the First Foods management approach and mission provide a coherent management and governance structure that is responsive to community requests for these resources and the order in which the First Foods are harvested and served.

In the first 10 years of implementing the First Foods management approach and mission, the DNR has emphasized the collective First Foods serving order over individual First Foods. The rationale is that doing so increases management responsiveness to the community, provides a direct connection with the promises made by all foods in the tribal creation belief, and reflects the phenology and geographic distribution of the foods in the serving order. For example, the seasonal progression of available foods follows an elevation gradient, beginning in the spring along the Columbia River, progressing into the mountains during the summer, and returning to the tributaries, like the Umatilla River, in the fall. The First Foods management approach has extended management efforts to encompass big game, roots, and berries and the full First Foods table setting more explicitly (Fig. 3). Big game efforts have included coordinating tribal harvest opportunities, such as the hunting of sensitive populations of bighorn sheep and mountain goats with ODFW and buffalo hunts with the Montana Fish, Wildlife, and Parks in 2009 because buffalo are unavailable for hunting on UIR (Figs. 8, 9). Root and berry efforts have included developing a traditional use report for huckleberry (Schumacher 2016) and mapping distributions of five root foods on 15,284 ha with United States Department of Agriculture Forest Service (USFS) in 2008 and another three root foods on an additional 52,768 ha with the Bureau of Land 
Management (BLM) in 2009. Root and berry efforts have also focused on coordinating tribal access for harvesting. For example, the DNR secured access through a Memorandum of Agreement (MOA) with a private energy developer for root digging access on isolated BLM parcels starting in 2007.

\section{EMERGING INSIGHTS FROM THE CTUIR'S FIRST DECADE OF IMPLEMENTING THE FIRST FOODS MANAGEMENT APPROACH}

Over the last 10 years, the DNR has gained insights into the First Foods approach and the ways in which it has benefited their management of culturally significant natural resources. Here, we provide examples of some benefits that may be meaningful to other tribal managers and, in some cases, nontribal managers.

\section{"Visionary" management that integrates science to support natural resource management and ecosystem resiliency}

The First Foods management approach and mission reflect an overarching management goal for the DNR that would help fulfill community requests for First Foods. However, they do not outline the scientific considerations and context necessary for restoring, protecting, and enhancing First Foods on and off the reservation. Thus, early in implementing the First Foods approach, the DNR identified the need for culturally consistent, management visions that were rooted in scientific knowledge to help "tribal and nontribal managers in moving the First Foods mission from concept to application" (Jones et al. 2008a:ii). Such visions can be helpful frameworks for planning management and restoration efforts, assessing success or failure, and considering specific management and restoration actions within the context of other actions (Jungwirth et al. 2002). To date, the CTUIR has developed the River Vision for water and salmon (Jones et al. 2008a), and is developing a complementary vision for the uplands that will encompass big game, roots, and berries. Common elements of the River Vision and forthcoming Uplands Vision are overviews of the critical processes and interactions supporting functional ecosystems and First Foods, ecosystem impairments, and some key challenges and questions for the management and restoration of First Foods. Here, we discuss the River Vision in more detail to illustrate how it connects First Foods, ecological and physical processes, and habitat restoration, and aids the DNR in its mission to protect and restore riverine First Foods.

The River Vision was the first CTUIR management vision developed in 2008, owing to staff capacity, the agency's emphasis on water and fisheries to date, and available resources. It described the management vision for rivers, water, and associated First Foods, such as salmon, trout, lamprey, whitefish, suckers, and mussels (Fig. 3). It summarized the interactions between five components (or "touchstones"), hydrology, geomorphology, connectivity, riparian vegetation, and aquatic biota, that shape resilient and functional rivers. It synthesized research done on the Umatilla River by DNR staff in collaboration with university scientists. This research highlighted how interactions between streamflow and geomorphic processes influence water exchange between the river channel and its alluvial aquifer (termed "hyporheic exchange"), thereby helping to buffer stream temperatures (Arrigoni et al. 2008, Jones et al. 2008b,c, Poole et al. 2008). Some outcomes of these hydrologic and geomorphic processes include thermal variability, habitat diversity, and upwelling hyporheic sites where salmon preferentially spawn
(Baxter and Hauer 2000, Geist et al. 2002). The River Vision explains the scientific underpinning of these processes and their relationships with riverine First Foods so that the CTUIR DNR has a solid scientific foundation for implementing First Foods management.

The River Vision also identifies potential hurdles to the First Foods mission related to water and fishes. In particular, the River Vision emphasizes the need for process-based restoration to address the causes of river ecosystem degradation (Kondolf et al. 2006, Beechie et al. 2010). Process-based restoration focuses on allowing hydrologic and geomorphic regimes to shape river corridors at spatial scales that match the spatial scale of problems attempting to be addressed through restoration (Poff et al. 1997, Roni et al. 2002, Beechie et al. 2010). Accordingly, the CTUIR DNR Fisheries Habitat Program has shifted from implementing site-scale projects (involving $10 \mathrm{~s}$ to $100 \mathrm{~s}$ of $\mathrm{m}$ of stream channel) to reach-scale projects (1000s of $\mathrm{m}$ in length) to improve habitat for listed salmonids and other riverine First Foods. This shift reflects the new understanding, shaped by the First Foods approach and River Vision, that successful habitat restoration must address larger scale processes that create habitat features suitable for salmonids, other native fishes, and mussels.

DNR staff has applied the processes and science synthesized in the River Vision to their implementation and monitoring of habitat restoration projects (Figs. 10, 11). One example of this new approach is the DNR's restoration of 2.6 kilometers along Meacham Creek, Oregon (Fig. 10), with the goals of improving salmonid habitat and restoring geomorphic processes and hyporheic exchange. Prior to restoration, Meacham Creek had been repeatedly rerouted away from the Union Pacific Railroad from 1890 to 2000 with a series of dikes and channel-straightening efforts (Andrus and Middel 2003). As a result, Meacham Creek lacked complex instream habitats, and was too warm for spring Chinook salmon, bull trout (Salvelinus confluentus), and summer steelhead (Richter and Kolmes 2005). The expressed purpose of the Meacham Creek restoration project was to restore hyporheic exchange in order to improve stream temperatures (CTUIR 2012). To accomplish this goal, the DNR, Bonneville Power Administration (BPA), and USFS did not rely on creating channel meanders (sensu Kondolf 2006), pools, or other structural habitat components. Instead, they moved the straightened channel, which had been dredged to bedrock, from the floodplain margin back to its historical position at the center of the floodplain, atop alluvial gravels. They also avoided the use of bank hardening structures that would prevent channel migration, and gave the channel room to move across its floodplain via active and dynamic geomorphic processes, such as avulsion, bank erosion, and sediment accretion, in response to high flow events over time. This restoration approach is consistent with the premises of processbased restoration, and allows the channel to be shaped by active hydrologic and geomorphic processes over time. Following restoration, surface waters in Meacham Creek now inundate the floodplain during flood events, and rework the floodplain and stream channel (Fig. 10). Re-establishing this interplay between hydrologic and geomorphic processes is a key part of restoring this gravel-bedded river and creating a geomorphic template that supports hyporheic exchange (Arrigoni et al. 2008, Poole et al. 2008, Hester and Gooseff 2010), improves water quality (Poole et al. 2004), and improves habitat conditions for salmonids and 
Fig. 10. Images of a portion of the Meacham Creek habitat restoration site: (A) Before restoration (8 June 2005), (B) Immediately after restoration (10 August 2012), and (C) Four years post restoration (3 June 2016). Images are from Google Earth.
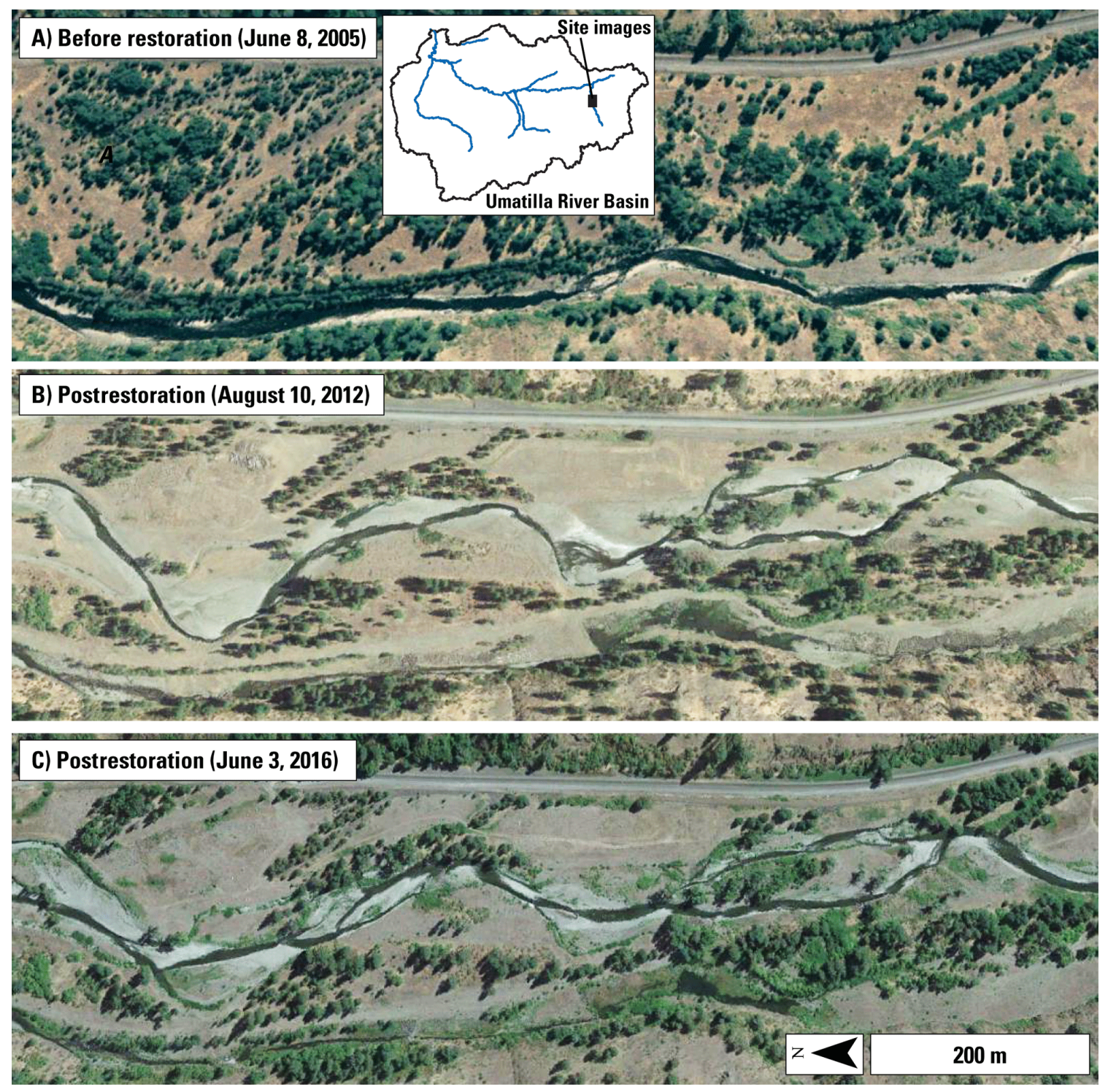

other riverine First Foods (Waples et al. 2009, Bellmore et al. 2013)

In sum, the River Vision provides a scientifically based, implementation road map for the First Foods management approach related to water and fishes. It acknowledges that First Foods themselves will be resilient to change when the touchstones and processes creating aquatic and floodplain habitats are intact (Jones et al. 2008a). The River Vision's scientific framework has helped DNR managers and staff identify the necessary touchstones for resilient ecosystems, pinpoint any adverse changes in these components, and implement daily and long-term mitigation and restoration actions in support of First Foods as illustrated by the Meacham Creek restoration project. It also helped DNR staff working on different river conservation and restoration objectives, such as water quality or salmon spawning habitats, to coordinate their management actions and planning efforts. Without the scientific roadmap of the River Vision, DNR staff would not have an explicit way of linking First Foods with ecological and physical processes, science, and habitat restoration approaches, nor would they have the scientific foundation for communicating their goals and objectives to the tribal community as well as federal, state, and local collaborators.

\section{Increased management of other natural resources}

Another tangible outcome of the First Foods mission was that it helped the DNR extend their management efforts beyond water, salmon, and other fishes to encompass big game, roots, and berries (Fig. 3). This was a fundamental shift in the agency's management in response to community requests' to protect the women's foods, 
Fig. 11. Linkages between First Foods, resource management visions, and management and habitat restoration actions. This figure focuses on the relationships between the River Vision, touchstones (or key components) of riverine ecosystems that support First Foods, and restoration actions and monitoring metrics related to addressing and measuring progress toward improving impaired habitat conditions. Images courtesy of the Integration and Application Network, University of Maryland Center for Environmental Science (http://ian. umces.edu/symbols/).

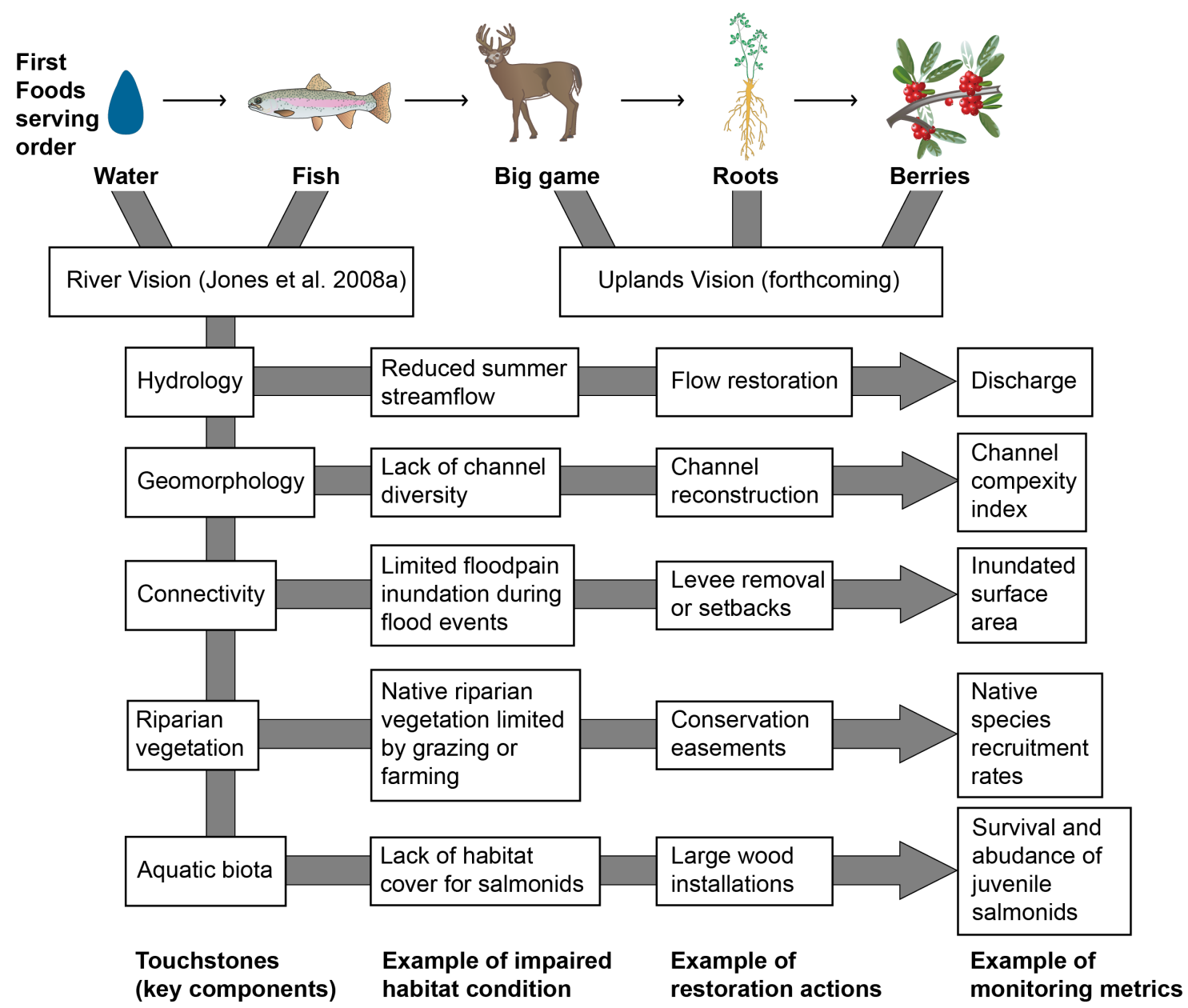

roots and berries, and access to them. Historically, the CTUIR did not have the management capacity to focus on these foods; as a result, the abundance of these foods and tribal access to them diminished over time. Since the adoption of the First Food approach and mission, the CTUIR governance and DNR have assessed the amount, distribution, and accessibility of these foods and developed responsive management actions. By explicitly addressing the entire First Foods serving order (Fig. 3), the DNR is being responsive to the values of all community food gatherers, helping to increase the community's understanding of the distribution and availability of foods, and focusing management attention and resources on the habitat needs of all foods and related tribal access. Proactive management of the full serving order increases the likelihood that food abundance and food access will meet community requirements and contribute to cultural continuity.
Building interagency collaboration for the comanagement of natural resources

The DNR actively works to manage natural resources on and off the reservation in collaboration with tribal, federal, state, and local agencies because the diminished reservation cannot provide the CTUIR community with an adequate supply of all First Foods (Fig. 2). In doing so, the DNR has found the First Foods approach and related management visions beneficial because they help communicate the cultural significance of First Foods to the CTUIR community, identify key processes supporting the First Foods, and assist DNR and nonindigenous agencies in identifying collaboration opportunities. The DNR's work on riverine First Foods with the River Vision provides the best illustrations of these points. The DNR works with at least seven federal agencies, five state agencies, and multiple local county and zoning agencies in their effort to improve and sustain water and fishes. These projects represent new and novel types of agreements between the CTUIR 
and cooperating agencies that are aided by the structure of the First Foods approach. In these collaborations, First Foods serve as focal points (or boundary objects, sensu Clark et al. 2011, Robinson and Wallington 2012), which enable the CTUIR to share the cultural significance of First Foods and have meaningful conversations with cooperating agencies. The scientific understanding of physical and ecological processes summarized in the River Vision has helped the DNR communicate the importance of critical ecological and physical processes that support First Foods, and helped other agencies to identify processes that are relevant to First Foods and within their mission areas. With this common ground, the DNR has built successful collaborations with other tribal and nontribal agencies to manage and restore resilient riverine ecosystems and First Foods.

The structure provided by the First Foods approach has also been helpful as the DNR establishes new state and federal cogovernance relationships to manage big game, roots, and berries. On the UIR, CTUIR DNR assumed the management responsibilities for the BIA Range and Agriculture Programs in 2008 and BIA Forestry Program in 2010. Since then, the CTUIR DNR has incorporated big game, roots, and berries into their management of grazing, farming, and forestry activities. The management directives for the prior BIA programs did not include or address First Foods, and focused on trust landowners receiving fair market value for extracted resources, such as timber harvest, grazing, and gravel. Further from the UIR, the CTUIR DNR successfully negotiated the re-establishment of tribal buffalo hunting in Montana with the Montana Fish, Wildlife, and Parks in 2009 (Fig. 8). This negotiation was supported by a CTUIR Cultural Resources Protection Program (2009) report, which documented the importance of buffalo as a traditional First Food to the CTUIR people using oral histories and outlined treaty protected rights for natural resource access and use within the context of the Walla Walla Treaty of 1855. The buffalo hunting agreement has significant implications for the CTUIR's treatyprotected rights to collect First Foods outside of previously defined areas and the UIR, because it provides a road map for CTUIR to use their research and First Foods management approach to help negotiate the re-establishment of traditional practices and harvesting opportunities.

\section{Culturally meaningful reporting units}

Adoption and implementation of the First Foods approach have given the DNR a culturally appropriate means of reporting the benefits associated with habitat restoration and other natural resource management actions to their community. This shifts the focus from reporting units that are disconnected from tribal culture to First Foods reporting units that reflect the values, traditions, and religion of the CTUIR community as well as dynamic and resilient ecosystem processes. In turn, the CTUIR community directly observes the diversity, regularity, and quality of First Foods that are available for feasts and everyday use. The CTUIR community can provide feedback on DNR efforts through community open houses, General Council meetings, and regulatory commission meetings. The DNR can then use the community-expressed needs and goals to inform work planning for research, assessments, and restoration plans that are reviewed and approved by tribal policy makers.
Transferability to other tribal and indigenous managers

The First Foods management approach is most directly transferable to other tribes and indigenous groups where community values and management goals are broadly shared and aligned with ecosystem resilience. Therefore, the DNR has helped convene workshops on traditional foods management, and presented and shared the First Foods with other indigenous groups (Fig. 9). Sharing successful strategies for indigenous and nonindigenous collaborations is important because some indigenous communities are reticent to share information on cultural significant resources because of fear of continued or increased exploitation of foods and resources that are sacred to them. For example, Pacific Northwest tribes have seen water overdeveloped and polluted, fish communities driven to extinction or endangered status, conflicts over big game harvest, and commercial exploitation of huckleberry and other First Foods. Understandably, some indigenous communities are reluctant to share data on the distributions of foods and resources with nonindigenous agencies and individuals. Nonetheless, an indigenous community's readiness and willingness to share information about its culturally significant foods and resources directly affects their ability to apply the First Foods management approach and collaborate with nonindigenous agencies.

Indigenous agencies can take steps to protect their resources when sharing sensitive information on culturally significant foods and resources and building collaborative relationships with nonindigenous agencies and individuals. In managing for First Foods with nontribal agencies and individuals, the DNR has used governance tools, such as policies, memoranda of understanding or agreement, and data sharing agreements that limit the specificity with which collaborating agencies can display or distribute information on culturally significant foods and resources. For example, the CTUIR has signed data sharing agreements with BLM and USFS for the women's food mapping projects and MOAs for access and harvesting on private properties. These types of governance tools and other guidelines have been shared with other indigenous communities by the Climate and Traditional Knowledges Workgroup to help protect ecological and traditional knowledge about species, harvesting locations, and traditional uses when sharing these types of data with nonindigenous partners (Climate and Traditional Knowledges Workgroup 2014). Other resources that discuss protecting traditional knowledge include Davis and Reid (1999), Lomawaima (2000) and Fisher and Ball (2003).

More broadly, because the First Foods approach as a strategy has assisted the CTUIR in maintaining and supporting its cultural values as expressed through the tribal creation belief, First Foods serving order (Fig. 3), and associated practices, we suggest the First Foods approach may offer similar benefits to other indigenous communities. The resurgence and re-expression of CTUIR tribal values through First Foods is evidence of the resilience and tenacity of tribal culture (sensu Rotarangi and Stephenson 2014). This adaptation strategy for tribal natural resource management aligns management goals with tribal community requests first and foremost, while also providing a path forward for building collaborations with nontribal agencies. Given that other indigenous communities have similarly experienced suppression of their natural resources, resource management, culture, and religious practices by Euro-American 
society, using a First Foods management approach, that is uniquely adapted to their culturally significant foods, ecosystems, and landscapes, may benefit their cultural resilience while also making their values and goals accessible to nonindigenous agencies and public.

\section{Communication with the nontribal public}

We end this overview of the CTUIR's First Foods approach with a reflection on communicating the cultural significance and management of First Foods with nontribal individuals. To date, staff from the CTUIR DNR has presented the First Foods approach over 100 times to other tribes and indigenous communities, state and federal agencies, local governments, universities, professional societies, and nongovernmental organizations. Staff has also shared the CTUIR's First Foods culture and management approach with over 18,200 K-12 public school students and over 12,000 adults at outreach and education events, primarily in northeastern Oregon and southeastern Washington, from 2008 to 2016. Informal feedback on these presentations received by the principal author, Eric Quaempts, indicates that three main messages resonate with the nontribal public. These messages may help nontribal individuals to consider First Foods, physical and ecological processes, and reciprocity in their own lives and to support the management, protection, and restoration of First Foods and ecosystem resilience.

The first message is that the First Foods approach aids people in making more personal and direct connections to the environment, through a shared understanding of the importance of food and food rituals, as it relates humans to functional and resilient ecosystems. This is probably because individuals from dissimilar backgrounds often share the collective human experience of certain foods symbolizing their family or community traditions (sensu Holtzman 2006). The second message is that the ecological groupings of foods (Fig. 3) and the spatial distribution of the serving order across the landscape (Fig. 2) underscore the importance of ecology and phenology and the need for functional landscapes encompassing rivers and floodplains up to the mountaintops. This is in alignment with our scientific understanding of ecosystems and the processes that sustain them. The third message is that individuals connect with the theme of reciprocity between the tribal community and First Foods. Reciprocity is an elegant connection between humans, foods, and landscapes that is an integral belief in many tribal and indigenous communities. Reciprocity counts human actions as an integral part of natural processes where a shared dependence is essential to the survival of both people and all other organisms. The importance of reciprocity may be reminiscent of the land ethic of Aldo Leopold (1970) to nonindigenous individuals with different belief systems, and may assist in making the cultural significance of managing and restoring First Foods more transferable to other individuals and communities. Further, unlike the concept of environmental sustainability where actions are summed to continental and global scales (Goodland 1995), the concept of reciprocity is inherently place based and bound by human harvest interactions across a landscape. Although a detailed discussion is outside the scope of this paper, we surmise that reciprocity may be a useful alternative to prevailing environmental concepts, such as sustainability, for connecting individuals with place, natural resource management, and habitat restoration. This is because reciprocity resonates on a personal level with individuals from different backgrounds and belief systems (sensu Ryan 2014). The applicability and effectiveness of reciprocity, as experienced by the CTUIR in the implementation of the First Foods approach, are worthy of more explicit consideration and inclusion by the environmental management and restoration community.

\section{CONCLUSION}

The CTUIR developed the First Foods management approach to be responsive to the community's requests for restored, sustainable, and accessible First Foods. Over the last 10 years, the First Foods approach has helped the DNR expand their efforts to include the entire First Foods serving order (Fig. 3). In applying this approach, the DNR emphasizes the reciprocal relationships between natural resources and humans. This is a deeply held and widely shared belief within the tribal community that means humans are responsible for taking care of the foods that provide sustenance to humans. This relationship is expressed in the concept of "reciprocity" between the community and the environment. Furthermore, the First Foods management approach provides the Tribal community with a means to "monitor" the performance of its government as the diversity, quality, and regularity of First Foods that can be harvested, served, and safely consumed are direct and meaningful indicators of the DNR's management effort and progress.

The First Foods management approach has improved intergovernmental and interagency understanding and collaboration for three reasons. First, through food, it relates humans to functional and resilient ecosystems, and assists people in making more personal and direct connections to the environment. Second, it provides cultural, ecological, and spatial frameworks for research and applied management and restoration. Third, it provides a means for communicating indigenous community values and goals to nonindigenous agencies and individuals. The transferability of the First Foods management to other indigenous managers is high where other indigenous communities are willing to safely share information about culturally significant foods and resources. Nonindigenous governments and management agencies can interact with First Foods management via the ecological and spatial relationships inherent in the First Foods serving order. They can also use this framework to improve their understanding of indigenous community goals, identify areas of management overlap and collaborative potential, and find ways to assist indigenous groups in caring for the foods and ecosystems that care for us all.

Responses to this article can be read online at: http://www.ecologyandsociety.org/issues/responses. php/10080

\section{Acknowledgments:}

We thank the community of the Confederated Tribes of the Umatilla Reservation (CTUIR) and staff of the CTUIR Department of Natural Resources (DNR) for their inspiration and efforts related to celebrating, recovering, and managing First Foods. We thank Jim Webster for his insights into the connections between 
the River Vision touchstones, habitat restoration, and effectiveness monitoring actions for the CTUIR Fisheries Habitat Program. We also thank Heather Bervid, Mackenzie Keith, Joseph Mangano, and Jackie Olson from USGS for their help preparing the manuscript. The CTUIR DNR and the U.S. Geological Survey Cooperative Matching Funds program supported this effort. Support for GCP'S participation in development of this paper provided by the Montana Agricultural Experiment Station.

\section{LITERATURE CITED}

Anderson, M. G., and C. E. Ferree. 2010. Conserving the stage: climate change and the geophysical underpinnings of species diversity. PLoS ONE 5(7):e11554. http://dx.doi.org/10.1371/ journal.pone.0011554

Andrus, C., and J. Middel. 2003. Meacham Creek watershed assessment and action plan. Prepared by Water Work Consulting and Duck Creek Associates, Corvallis, Oregon, USA.

Arrigoni, A. S., G. C. Poole, L. A. K. Mertes, S. J. O'Daniel, W. W. Woessner, and S. A. Thomas. 2008. Buffered, lagged, or cooled? Disentangling hyporheic influences on temperature cycles in stream channels. Water Resources Research 44:W09418. http://dx. doi.org/10.1029/2007WR006480

Baxter, C. V., and F. R. Hauer. 2000. Geomorphology, hyporheic exchange, and selection of spawning habitat by bull trout (Salvelinus confluentus). Canadian Journal of Fisheries and Aquatic Sciences 57(7):1470-1481. http://dx.doi.org/10.1139/ $\underline{\mathrm{f00}-056}$

Beechie, T., H. Imaki, J. Greene, A. Wade, H. Wu, G. Pess, P. Roni, J. Kimball, J. Stanford, P. Kiffney, and N. Mantua. 2013. Restoring salmon habitat for a changing climate. River Research and Applications 29(8):939-960. http://dx.doi.org/10.1002/ $\underline{\operatorname{rra} .2590}$

Beechie, T. J., D. A. Sear, J. D. Olden, G. R. Pess, J. M. Buffington, H. Moir, P. Roni, and M. M. Pollock. 2010. Process-based principles for restoring river ecosystems. BioScience 60 (3):209-222.

Beier, P., and B. Brost. 2010. Use of land facets to plan for climate change: conserving the arenas, not the actors. Conservation Biology 24(3):701-710. http://dx.doi.org/10.1111/j.1523-1739.2009.01422. $\underline{\mathrm{x}}$

Bellmore, J. R., C. V. Baxter, K. Martens, and P. J. Connolly. 2013. The floodplain food web mosaic: a study of its importance to salmon and steelhead with implications for their recovery. Ecological Applications 23(1):189-207. http://dx.doi.org/10.1890/12-0806.1

Blumm, M. C., and B. M. Swift. 1998. The Indian Treaty Piscary profit and habitat protection in the Pacific Northwest: a property rights approach. University of Colorado Law Review 69:407.

Boyce, R. R. 1986. A comprehensive plan for rehabilitation of anadromous fish stocks in the Umatilla River Basin. BPA Contract No. DE-AI79-84BP18008, Project No. 84-10, Bonneville Power Administration, Portland, Oregon, USA.

Carey, M. P., B. L. Sanderson, T. A. Friesen, K. A. Barnas, and J. D. Olden. 2011. Smallmouth bass in the Pacific Northwest: a threat to native species; a benefit for anglers. Reviews in Fisheries Science 19(3):305-315. http://dx.doi.org/10.1080/10641262.2011.598584

Chapin, F. S., S. R. Carpenter, G. P. Kofinas, C. Folke, N. Abel, W. C. Clark, P. Olsson, D. M. Stafford Smith, B. Walker, O. R. Young, F. Berkes, R. Biggs, J. M. Grove, R. L. Naylor, E. Pinkerton, W. Steffen, and F. J. Swanson. 2010. Ecosystem stewardship: sustainability strategies for a rapidly changing planet. Trends in Ecology \& Evolution 25(4):241-249. http://dx. doi.org/10.1016/j.tree.2009.10.008

Chapin, F. S., III, S. T. A. Pickett, M. E. Power, R. B. Jackson, D. M. Carter, and C. Duke. 2011. Earth stewardship: a strategy for social-ecological transformation to reverse planetary degradation. Journal of Environmental Studies and Sciences 1(1):44-53. http:// dx.doi.org/10.1007/s13412-011-0010-7

Clark, W. C., T. P. Tomich, M. van Noordwijk, D. Guston, D. Catacutan, N. M. Dickson, and E. McNie. 2011. Boundary work for sustainable development: natural resource management at the Consultative Group on International Agricultural Research (CGIAR). Proceedings of the National Academy of Sciences 17:4615-4622.

Climate and Traditional Knowledges Workgroup. 2014. Guidelines for considering traditional knowledges in climate change initiatives. Climate and Traditional Knowledges Workgroup. [online] URL: https://climatetkw.wordpress.com

Close, D. A., M. Fitzpatrick, H. Li, B. Parker, D. Hatch, and G. James. 1995. Status report of the Pacific Lamprey (Lampetra tridentata) in the Columbia River basin. Report prepared for the Bonneville Power Administration, Portland, Oregon, USA.

Cochran, P. L., and A. L. Geller. 2002. The melting ice cellar: what native traditional knowledge is teaching us about global warming and environmental change. American Journal of Public Health 92(9):1404-1409. http://dx.doi.org/10.2105/AJPH.92.9.1404

Confederated Tribes of the Umatilla Indian Reservation (CTUIR). 2005. Department of Natural Resources annual work plan. Confederated Tribes of the Umatilla Indian Reservation, Mission, Oregon, USA.

Confederated Tribes of the Umatilla Indian Reservation (CTUIR). 2006. Department of Natural Resources annual work plan. Tribal Resolution \#06-116. Confederated Tribes of the Umatilla Indian Reservation, Mission, Oregon, USA.

Confederated Tribes of the Umatilla Indian Reservation (CTUIR). 2012. Meacham Creek floodplain restoration and instream enhancement project completion report. Tetra Tech, Inc., Bothell, Washington, USA.

Confederated Tribes of the Umatilla Indian Reservation v. U.S. 1959. Tribal territories and village locations of the Walla Walla, Cayuse, and Umatilla Tribes. Docket 264. Reports of the Indian Claims Commission, Washington, D.C., USA.

Confederated Umatilla Journal. 2008. Putting First Foods first. Confederated Umatilla Journal Pendleton, Oregon, USA.

Davis, S. M, and R. Reid. 1999. Practicing participatory research in American Indian communities. American Journal of Clinical Nutrition 69(4):755S-759S. http://dx.doi.org/10.1093/ajen/69.4.755S 
Fisher, A. H. 1997. The 1932 handshake agreement: Yakama Indian treaty rights and Forest Service policy in the Pacific Northwest. Western Historical Quarterly 28(2):186-217. http://dx. doi.org/10.2307/970893

Fisher, P. A., and T. J. Ball. 2003. Tribal participatory research: mechanisms of a collaborative model. American Journal of Community Psychology 32(3-4):207-216. http://dx.doi.org/10.1023/ B:AJCP.0000004742.39858.c5

Folke, C., S. Carpenter, B. Walker, M. Scheffer, T. Elmqvist, L. Gunderson, and C. S. Holling. 2004. Regime shifts, resilience, and biodiversity in ecosystem management. Annual Review of Ecology, Evolution, and Systematics 35(1):557-581. http://dx.doi. org/10.1146/annurev.ecolsys.35.021103.105711

Folke, C., C. S. Holling, and C. Perrings. 2010. Biological diversity, ecosystems, and the human scale. Pages 151-166 in L. H. Gunderson, C. R. Allen, and C. S. Holling, editors. Foundations of ecological resilience. Island, Washington, D.C., USA.

Galanda, G. 2011. The federal Indian consultation right: a frontline defense against tribal sovereignty incursion. American Business Law Government Affairs Practice Committee Newsletter 2(1).

Geist, D. R., T. P. Hanrahan, E. V. Arntzen, G. A. McMichael, C. J. Murray, and Y. Chien. 2002. Physicochemical characteristics of the hyporheic zone affect redd site selection by chum salmon and fall Chinook salmon in the Columbia River. North American Journal of Fisheries Management 22(4):1077-1085. http://dx.doi. org/10.1577/1548-8675(2002)022<1077:PCOTHZ>2.0.CO;2

Goodland, R. 1995. The concept of environmental sustainability. Annual Review of Ecology and Systematics 26(1):1-24. http://dx. doi.org/10.1146/annurev.es.26.110195.000245

Gresh, T., J. Lichatowich, and P. Schoonmaker. 2000. An estimation of historic and current levels of salmon production in the Northeast Pacific ecosystem: evidence of a nutrient deficit in the freshwater systems of the Pacific Northwest. Fisheries 25 (1):15-21. http://dx.doi.org/10.1577/1548-8446(2000)025<0015: $\underline{\mathrm{AEOHAC}}>2.0 . \mathrm{CO} ; 2$

Grimm, V., and C. Wissel. 1997. Babel, or the ecological stability discussions: an inventory and analysis of terminology and a guide for avoiding confusion. Oecologia 109(3):323-334. http://dx.doi. org/10.1007/s004420050090

Gunderson, L. H. 2000. Ecological resilience-in theory and application. Annual Review of Ecology and Systematics 31 (1):425-439. http://dx.doi.org/10.1146/annurev.ecolsys.31.1.425

Hess, J. J., J. N. Malilay, and A. J. Parkinson. 2008. Climate change - the importance of place. American Journal of Preventive Medicine 35(5):468-478. http://dx.doi.org/10.1016/j.amepre.2008.08.024

Hester, E. T. and M. N. Gooseff. 2010. Moving beyond the banks: hyporheic restoration is fundamental to restoring ecological services and functions of streams. Environmental Science \& Technology 44(5):1521-1525. http://dx.doi.org/10.1021/es902988n

Holling, C. S. 1973. Resilience and stability of ecological systems. Annual Review of Ecology and Systematics 4(1):1-23. http://dx. doi.org/10.1146/annurev.es.04.110173.000245
Holtzman, J. D. 2006. Food and memory. Annual Review of Anthropology 35:361-378. http://dx.doi.org/10.1146/annurev. anthro.35.081705.123220

Horizon Systems. 2013. NHDPlusV2Data: Horizon Systems database. [online] URL: http://www.horizon-systems.com/ nhdplus/

Hunn, E. S., E. T. Morning Owl, P. E. Cash Cash, and J. Karson Engum. 2015. Cáw Pawá Láakni / They are not forgotten: Sahaptian place names atlas of the Cayuse, Umatilla, and Walla Walla. Confederated Tribes of the Umatilla Indian Reservation, Tamástslikt Cultural Institute, Pendleton, Oregon, USA.

Jones, K. L., G. C. Poole, S. J. O'Daniel, L. A. K. Mertes, and J. A. Stanford. 2008b. Surface hydrology of low-relief landscapes: assessing surface water flow impedance using LIDAR-derived digital elevation models. Remote Sensing of Environment 112:4148-4158. http://dx.doi.org/10.1016/j.rse.2008.01.024

Jones, K. L., G. C. Poole, E. J. Quaempts, S. O'Daniel, and T. Beechie. 2008a. Umatilla River Vision. Confederated Tribes of the Umatilla Indian Reservation, Mission, Oregon, USA. [online] URL: http://www.ykfp.org/par10/html/CTUIR \%20DNR \%20Umatilla\% 20River $\% 20$ Vision $\% 20100108$.pdf

Jones, K. L., G. C. Poole, W. W. Woessner, M. V. Vitale, B. R. Boer, S. J. O'Daniel, S. A. Thomas, and B. A. Geffen. $2008 c$. Geomorphology, hydrology, and aquatic vegetation drive seasonal hyporheic flow patterns across a gravel-dominated floodplain. Hydrological Processes 22:2105-2113. http://dx.doi. org/10.1002/hyp.6810

Jungwirth, M., S. Muhar, and S. Schmutz. 2002. Re-establishing and assessing ecological integrity in riverine landscapes. Freshwater Biology 47(4):867-887. http://dx.doi.org/10.1046/ j.1365-2427.2002.00914.X

Karson, J., editor. 2006. Wiyaxayxt / Wiyaakaa'awn = As days go by: our history, our land, our people -- the Cayuse, Umatilla, and Walla Walla. University of Washington Press, Seattle, Washington, USA.

Kondolf, G. M. 2006. River restoration and meanders. Ecology and Society 11(2):42 http://dx.doi.org/10.5751/ES-01795-110242

Kondolf, G. M., A. J. Boulton, S. O'Daniel, G. C. Poole, F. J. Rahel, E. H. Stanley, E. Wohl, A. Bång, J. Carlstrom, C. Cristoni, H. Huber, S. Koljonen, P. Louhi, and K. Nakamura. 2006. Process-based ecological river restoration: visualizing threedimensional connectivity and dynamic vectors to recover lost linkages.. Ecology and Society 11(2):5. http://dx.doi.org/10.5751/ ES-01747-110205

Kuhnlein, H. V., and O. Receveur. 1996. Dietary change and traditional food systems of indigenous peoples. Annual Review of Nutrition 16(1):417-442. http://dx.doi.org/10.1146/annurev. nu.16.070196.002221

Leopold, A. 1970. A Sand County almanac: with other essays on conservation from Round River. Ballantine Books, New York City, New York, USA.

Lomawaima, K. T. 2000. Tribal sovereigns: reframing research in American Indian education. Harvard Educational Review 70 (1):1-23. http://dx.doi.org/10.17763/haer.70.1.b133t0976714n73r 
Miller, S. W., D. Wooster, and J. Li. 2007. Resistance and resilience of macroinvertebrates to irrigation water withdrawals. Freshwater Biology 52:2492-2510. http://dx.doi.org/10.1111/j.1365-2427.2007.01850. $\underline{x}$

Minore, D. 1972. The wild huckleberries of Oregon and Washington: a dwindling resource. Pacific Northwest Forest and Range Experiment Station, U.S. Department of Agriculture, Portland, Oregon, USA. http://dx.doi.org/10.5962/bhl.title.87986

Minore, D., A. W. Smart, and M. B. Dubrasich. 1979. Huckleberry and ecology management research in the Pacific Northwest. General Technical Report PNW-GTR-093. U.S. Forest Service, Pacific Northwest Research Station, Portland, Oregon, USA.

Montgomery, D. R. 2003. King of fish: the thousand-year run of salmon. Westview Press, Boulder, Colorado, USA.

Peipoch, M., M. Brauns, F. R. Hauer, M. Weitere, and H. M. Valett. 2015. Ecological simplification: human influences on riverscape complexity. BioScience 65:1057-1065. http://dx.doi. org/10.1093/biosci/biv120

Pevar, S. 2012. The rights of Indians and tribes. Oxford University Press, Oxford, UK.

Phillips, J. L., J. Ory, and A. Talbot. 2000. Anadromous salmonid recovery in the Umatilla River basin, Oregon: a case study. Journal of the American Water Resources Association 36:1287-1308. http://dx.doi.org/10.1111/j.1752-1688.2000.tb05727.x

Poff, N. L., J. D. Allan, M. B. Bain, J. R. Karr, K. L. Prestegaard, B. D. Richter, R. E. Sparks, and J. C. Stromberg. 1997. The natural flow regime: a paradigm for riverine conservation and restoration. BioScience 47:769-784. http://dx.doi.org/10.2307/1313099

Poole, G. C., J. B. Dunham, D. M. Keenan, S. T. Sauter, D. A. McCullough, C. Mebane, J. C. Lockwood, D. A. Essig, M. P. Hicks, D. J. Sturdevant, E. J. Materna, S. A. Spalding, J. Risley, and M. Deppman. 2004. The case for regime-based water quality standards. Bioscience 54:155-161. http://dx.doi.org/10.1641/0006-3568 (2004)054[0155:TCFRWQ]2.0.CO;2

Poole, G. C., S. J. O'Daniel, K. L. Jones, W. W. Woessner, E. S. Bernhardt, A. M. Helton, J. A. Stanford, B. R. Boer, and T. J. Beechie. 2008. Hydrologic spiralling: the role of multiple interactive flow paths in stream ecosystems. River Research and Applications 24(7):1018-1031. http://dx.doi.org/10.1002/rra.1099

Relander, C. 1986. Drummers and dreamers. Northwest Interpretive Association, Seattle, Washington, USA.

Richter, A., and S. A. Kolmes. 2005. Maximum temperature limits for Chinook, coho, and chum salmon, and steelhead trout in the Pacific Northwest. Reviews in Fisheries Science 13(1):23-49. http://dx.doi.org/10.1080/10641260590885861

Robinson, C. J., and T. J. Wallington. 2012. Boundary work: engaging knowledge systems in co-management of feral Animals on indigenous lands. Ecology and Society 17(2):16. http://dx.doi. org/10.5751/ES-04836-170216

Roni, P., T. J. Beechie, R. E. Bilby, F. E. Leonetti, M. M. Pollock, and G. R. Pess. 2002. A review of stream restoration techniques and a hierarchical strategy for prioritizing restoration in Pacific Northwest watersheds. North American Journal of Fisheries
Management 22(1):1-20. http://dx.doi.org/10.1577/1548-8675 (2002)022<0001:AROSRT>2.0.CO;2

Rotarangi, S. J., and J. Stephenson. 2014. Resilience pivots: stability and identity in a social-ecological-cultural system. Ecology and Society 19(1):28. http://dx.doi.org/10.5751/ ES-06262-190128

Ryan, J. C. 2014. Toward an ethics of reciprocity: ethnobotanical knowledge and medicinal plants as cancer therapies. Humanities 3(4):624-644. http://dx.doi.org/10.3390/h3040624

Schumacher, S. 2014. Landscape models to predict the locations of culturally important roots in NW Oregon. Confederated Tribes of the Umatilla Indian Reservation Department of Natural Resources, Mission, Oregon, USA.

Schumacher, S. 2016. Potential huckleberry distribution huckleberry throughout the Blue Mountains of $N W$ region and $S W$ Washington. Confederated Tribes of the Umatilla Indian Reservation Department of Natural Resources, Mission, OR.

Shelley, C. W. 2002. The resurrection of a river: the Umatilla and its salmon. Thesis. Portland State University, Portland, Oregon, USA. http://dx.doi.org/10.15760/etd.5869

Umatilla-Morrow Counties Community Health Partnership. 2016. Umatilla-Morrow Counties Community Health Assessment Report 2015-2016. Umatilla-Morrow Counties Community Health Partnership, Pendleton, Oregon, USA. [online] URL: http://www.co.umatilla.or.us/health/img/UmatillaMorrowCountiesHealthAssessment.pdf

Waples, R. S., T. Beechie, and G. R. Pess. 2009. Evolutionary history, habitat disturbance regimes, and anthropogenic changes: What do these mean for resilience of Pacific salmon populations? Ecology and Society 14(1):3. http://dx.doi.org/10.5751/ES-02626-140103

Williams, R. N., J. A. Stanford, J. A. Lichatowich, W. J. Liss, C. C. Coutant, W. E. McConnaha, R. R. Whitney, P. R. Mundy, P. A. Bisson, and M. S. Powell. 2006. Strategies for salmon restoration in the Columbia River Basin. Pages 629-666 in R. N. Williams, editor. Return to the river: restoring salmon to the Columbia River. Elsevier Academic, Amsterdam, The Netherlands. http://dx.doi.org/10.1016/B978-012088414-8/50016-3 